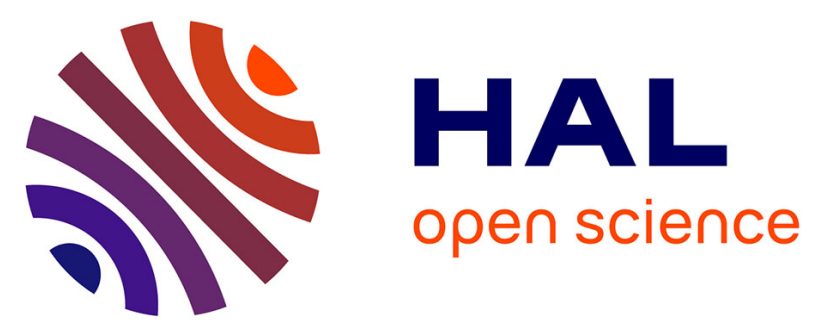

\title{
High-Resolution 1.5-Tesla Magnetic Resonance Imaging for Tissue-Engineered Constructs: A Noninvasive Tool to Assess Three-Dimensional Scaffold Architecture and Cell Seeding
}

\author{
Marie Poirier-Quinot, Guillaume Frasca, Claire Wilhelm, Nathalie Luciani, \\ Jean-Christophe Ginefri, Luc Darrasse, Didier Letourneur, Catherine Le \\ Visage, Florence Gazeau
}

\section{- To cite this version:}

Marie Poirier-Quinot, Guillaume Frasca, Claire Wilhelm, Nathalie Luciani, Jean-Christophe Ginefri, et al.. High-Resolution 1.5-Tesla Magnetic Resonance Imaging for Tissue-Engineered Constructs: A Noninvasive Tool to Assess Three-Dimensional Scaffold Architecture and Cell Seeding. Tissue Engineering Part C: Methods, 2010, 16 (2), pp.185-200. 10.1089/ten.tec.2009.0015 . hal-02269959

\section{HAL Id: hal-02269959 https://hal.science/hal-02269959}

Submitted on 23 Aug 2019

HAL is a multi-disciplinary open access archive for the deposit and dissemination of scientific research documents, whether they are published or not. The documents may come from teaching and research institutions in France or abroad, or from public or private research centers.
L'archive ouverte pluridisciplinaire HAL, est destinée au dépôt et à la diffusion de documents scientifiques de niveau recherche, publiés ou non, émanant des établissements d'enseignement et de recherche français ou étrangers, des laboratoires publics ou privés. 


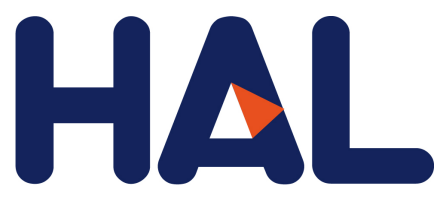

archives-ouvertes

\section{High-Resolution 1.5-Tesla Magnetic Resonance Imaging for Tissue-Engineered Constructs: A Noninvasive Tool to Assess Three-Dimensional Scaffold Architecture and Cell Seeding}

Marie Poirier-Quinot, Guillaume Frasca, Claire Wilhelm, Nathalie Luciani, Jean-Christophe Ginefri, Luc Darrasse, Didier Letourneur, Catherine Le Visage, Florence Gazeau

\section{To cite this version:}

Marie Poirier-Quinot, Guillaume Frasca, Claire Wilhelm, Nathalie Luciani, Jean-Christophe Ginefri, et al.. High-Resolution 1.5-Tesla Magnetic Resonance Imaging for Tissue-Engineered Constructs: A Noninvasive Tool to Assess Three-Dimensional Scaffold Architecture and Cell Seeding. Tissue Engineering Part C: Methods, Mary Ann Liebert, 2010, 16 (2), pp.185-200. 10.1089/ten.tec.2009.0015 . hal-02269959

\section{HAL Id: hal-02269959 \\ https://hal.archives-ouvertes.fr/hal-02269959}

Submitted on 23 Aug 2019

HAL is a multi-disciplinary open access archive for the deposit and dissemination of scientific research documents, whether they are published or not. The documents may come from teaching and research institutions in France or abroad, or from public or private research centers.
L'archive ouverte pluridisciplinaire HAL, est destinée au dépôt et à la diffusion de documents scientifiques de niveau recherche, publiés ou non, émanant des établissements d'enseignement et de recherche français ou étrangers, des laboratoires publics ou privés. 


\section{High-Resolution 1.5-Tesla Magnetic Resonance Imaging for Tissue-Engineered Constructs: A Noninvasive Tool to Assess Three-Dimensional Scaffold Architecture and Cell Seeding}

Marie Poirier-Quinot, ${ }^{1}$ Guillaume Frasca, ${ }^{2}$ Claire Wilhelm, ${ }^{2}$ Nathalie Luciani, ${ }^{2}$ Jean-Christophe Ginefri, ${ }^{1}$ Luc Darrasse, Didier Letourneur, ${ }^{3}$ Catherine Le Visage, ${ }^{3}$ and Florence Gazeau ${ }^{2}$

Tissue-engineered scaffolds are made of biocompatible polymers with various structures, allowing cell seeding, growth, and differentiation. Noninvasive imaging methods are needed to study tissue-engineered constructs before and after implantation. Here, we show that high-resolution magnetic resonance imaging (MRI) performed on a clinical 1.5-T device is a reliable technique to assess three-dimensional structures of porous scaffolds and to validate cell-seeding procedures. A high-temperature superconducting detection coil was used to achieve a resolution of $30 \times 30 \times 30 \mu \mathrm{m}^{3}$ when imaging the scaffolds. Three types of structures with tuneable architectures were prepared from naturally derived polysaccharides and evaluated as scaffolds for mesenchymal stem cell (MSC) culture. To monitor cell seeding, MSCs were magnetically labeled using simple incubation with anionic citrate-coated iron-oxide nanoparticles for $30 \mathrm{~min}$. Iron uptake was quantified using single-cell magnetophoresis, and cell proliferation was checked for 7 days after labeling. Three-dimensional (3D) microstructures of scaffolds were assessed using MRI, revealing lamellar or globular porous organization according to the scaffold preparation process. MSCs with different iron load (5, 12 and $31 \mathrm{pg}$ of iron per cell) were seeded on scaffolds at low density $\left(132\right.$ cells $/ \mathrm{mm}^{3}$ ) and detected on 3D gradient-echo MR images according to phase distortions and areas of intensely low signal, whose size increased with cell iron load and echo time. Overall signal loss in the scaffold correlated with the number of seeded cells and their iron load. Different organizations of cells were observed depending on the scaffold architecture. After subcutaneous implantation in mice, scaffolds seeded with labeled cells could be distinguished in vivo from scaffold with nonlabeled cells by observation of signal and phase heterogeneities and by measuring the global signal loss. High-resolution 1.5-T MRI combined with efficient intracellular contrast agents shows promise for noninvasive 3D visualization of tissue-engineered constructs before and after in vivo implantation.

\section{Introduction}

$\mathbf{R}$ ECENT DEVELOPMENTS in the field of regenerative medicine have yielded a novel set of tissue replacement parts and implementation strategies. Scientific advances in biomaterials, stem cells, and growth and differentiation factors elicit unique opportunities to create biomimetic environments and fabricate tissues from combinations of engineered extracellular scaffolds, cells, and biologically active molecules. Cell therapy should also benefit from implantation of scaffolds, allowing cell retention instead of direct injection of therapeutic cells in the targeted organ. ${ }^{1}$ Among the challenges facing regenerative medecine today is the need for noninvasive imaging methods to monitor the fate of transplanted cells or tissue constructs. Different imaging modalities, such as $\mathrm{X}$-ray computed tomography, optical microscopy, and magnetic resonance imaging (MRI), are being evaluated for assessment of tissue regeneration. ${ }^{2,3}$ MRI overcomes some limitations of optical and $\mathrm{x}$-ray imaging, depth limitations and ionizing radiation, respectively, and provides nondestructive three-dimensional (3D) imaging of tissues in vivo and in vitro with submillimeter resolution. Two recent advances in MRI make it more and

\footnotetext{
${ }^{1}$ Unité de Recherche en Résonance Magnétique Médicale, CNRS UMR 8081 CNRS - Université Paris Sud, centre médical, Université Paris Sud, Orsay, France.

${ }^{2}$ Laboratoire Matière et Systèmes Complexes, UMR 7057 CNRS, Université Paris, Diderot, Paris France.

${ }^{3}$ Inserm U698, Bio-ingénierie Cardiovasculaire, CHU X. Bichat, Paris, France.
} 
more attractive in the field of tissue engineering and cell therapy; the spatial resolution can be increased to near-cellular resolution $(30 \mu \mathrm{m})$, and the use of intracellular iron oxide contrast agent has rendered a specific cell population "visible."

MRI combined with magnetic cell labeling has been proven effective for noninvasive tracking of in vivo cell graft, ${ }^{4,5}$ including stem cells. ${ }^{6-9}$ Different groups have demonstrated the ability of MRI to image specific cells at the single-cell level, ${ }^{10-15}$ but this approach was proposed only recently for visualization of cells seeded in biological or synthetic 3D scaffolds intended for tissue reconstruction and in vivo implantation. ${ }^{16-18}$

Here, we evaluated the use of high-resolution MRI as a noninvasive imaging technique to assess scaffolds and cellular constructs. We took advantage of high spatial resolution and cell labeling with iron oxide nanoparticles to visualize the 3D architecture of scaffolds and the distribution of magnetically labeled mesenchymal stem cells (MSCs) seeded in these scaffolds.

To enhance MRI spatial resolution, it is necessary to increase the signal to noise ratio (SNR) in a voxel. The general strategy is to enhance the magnetic field strength for increasing the proton magnetization, which gives the signal, but high-field MRI is not clinically available and has several limitations such as reduced bore size, susceptibility artefacts, and high cost. Here we propose an alternative approach, in which the detection noise is reduced by using a high-temperature superconducting (HTS) cryo-cooled detection coil. A gain in SNR approximately 15 times as great as an identical copper coil is achieved on a nonconductive sample. This unique detection device enables a spatial resolution of up to $30 \mu \mathrm{m}$ in the three directions while operating on a clinical 1.5-T MRI. ${ }^{19}$

In the present article, high-resolution 1.5-T MRI was tested to investigate 3D scaffolds consisting of biocompatible polysaccharide-based hydrogels, previously evaluated as biomaterials for vascular engineering. ${ }^{20,21}$ The type of scaffold-building process led to different architectures of hydrogels, which were readily observable using MRI. Because scaffold structure is known to influence cell-seeding efficiency and cell organization within the scaffold, the second objective of the article was to evaluate cell seeding using MRI combined with magnetically labeled mesenchymal stem cells (MSCs).

For this purpose, we validated anionic maghemite nanoparticles (AMNPs) as an efficient and nontoxic intracellular label for human MSCs. This cell-labeling method has been demonstrated to work for a wide variety of cell types without impairing cell proliferation and functionalities. ${ }^{22}$ Nanoparticles confined in cell endosomes serve as high local sources of magnetic field, dephasing the magnetization of surrounding protons and creating a signal void in the cell vicinity. In this way, cell seeding on the scaffold could be assessed and quantified. To characterize the sensitivity of MRI for detecting seeded cells, we investigated parameters such as the number of cells, the labeling conditions, and the acquisition conditions (resolution and echo time). Detectability of scaffolds and associated seeded cells was also assessed in vivo after their implantation in mice.

\section{Materials and Methods}

\section{Porous scaffold preparation}

Porous globular polysaccharide-based scaffolds. Polysaccharide-based scaffolds were prepared using a mix- ture of pullulan and dextran (75:25) with a total concentration in water of $24.5 \%(\mathrm{w} / \mathrm{v})$ (pullulan, molecular weight (MW) 200,000, Hayashibara Inc., Okayama, Japan; dextran MW 500,000, Pharmacia, Uppsala, Sweden), according to a previously described protocol. ${ }^{20,21}$ Chemical cross-linking of polysaccharides was performed using the cross-linking agent sodium trimetaphosphate (STMP) $(11 \%(\mathrm{w} / \mathrm{v})$, Sigma, St. Louis $\mathrm{MO}$ ) under alkaline conditions $(10 \mathrm{M}$ sodium hydroxide). To obtain micro- and macroporous globular structures, the cross-linking process was performed on the frozen mixture during a freeze-drying process ${ }^{23}$ under freeze-drying pressures of $6.5 \mathrm{mbar}$ and $0.1 \mathrm{mbar}$, respectively. Scaffolds were freeze-dried for $48 \mathrm{~h}$ to allow the complete removal of water. Resulting freeze-dried scaffolds were rehydrated and washed in phosphate buffered saline (1X) (PBS; pH 7.4) and stored in PBS at $4^{\circ} \mathrm{C}$ until analysis.

Porous lamellar polysaccharide-based scaffolds. Porous lamellar polysaccharide-based scaffolds were prepared using the above formulation, and pores were created using a gasfoaming technique ${ }^{24}$ using sodium carbonate in $20 \%$ acetic acid solution. Resulting scaffolds were washed extensively with PBS (pH 7.4) and then with distilled water for at least 2 days. After a freeze-drying step, porous scaffolds with lamellar organization were obtained and stored at room temperature until use.

Fluorescent polysaccharide-based scaffolds. To perform confocal microscopy, fluorescent scaffolds were prepared by adding $1 \%$ fluorescein isothiocyanate (FITC) dextran (Sigma) to the mixture before cross-linking. Scaffolds were hydrated with PBS, and optical sections were acquired using a Zeiss LSM 510 confocal microscope (Carl Zeiss, Oberkochen, Germany) equipped with a $10 \times$ Plan-NeoFluar objective lens (numerical aperture of 0.3; Carl Zeiss). FITC-dextran was excited at $488 \mathrm{~nm}$ using an argon laser, and its fluorescent emission was selected using a 505- to 530-nm bandpass filter. Pore size was assessed using ImageJ from confocal images segmented according to a fluorescence intensity threshold with three scaffolds per condition and a total of 1044 measurements and 1786 measurements collected for micro- and macroporous scaffolds, respectively.

Scaffold preparation for MRI. For MR imaging of scaffolds in vitro, cylinders of $4 \mathrm{~mm}$ diameter and 2 to $3 \mathrm{~mm}$ thickness were cut up on hydrated porous globular and freeze-dried lamellar porous scaffolds. They were placed into containers consisting of a hollow plastic cylinder $(8 \mathrm{~mm}$ outer diameter, $5 \mathrm{~mm}$ inner diameter, $6 \mathrm{~mm}$ height) sealed on the back with a glass lamella. The containers were then filled with PBS and allowed to equilibrate for 4 days to eliminate air bubbles before imaging. The absence of bubbles was checked using microscopy examination.

\section{Culture and magnetic labeling of MSCs}

Human MSCs were isolated from bone marrow donors with CHR approval and provided by F. Norol (PitiéSalpétrière Hospital, Paris). MSCs were cultured at $37^{\circ} \mathrm{C}$ and $5 \%$ carbon dioxide $\mathrm{CO}_{2}$ in Dulbecco's modified Eagle medium supplemented with $10 \%$ fetal calf serum, $1 \%$ penicillin/ streptomycin, and $1 \%$ glutamin. Cells were not used beyond passage 6 . 
Citrate-coated AMNPs with a diameter of $8 \mathrm{~nm}$ (provided by C. Menager, University Pierre et Marie Curie) were used for cell labeling, as previously described. ${ }^{22}$ Cells were incubated for $30 \mathrm{~min}$ at $37^{\circ} \mathrm{C}$ in serum-free RPMI medium supplemented with $5 \mathrm{mM}$ sodium citrate and with AMNPs at iron concentrations of $[\mathrm{Fe}]=0,0.05,0.1,0.2,0.5,1,2,5$, and $10 \mathrm{mM}$. A chase period of $1 \mathrm{~h}$ in particle-free culture medium followed the incubation step to achieve complete internalization of the nanoparticles.

Iron load per cell was then quantified using the single-cell magnetophoresis experiment, which consists of measuring the velocity of labeled cells in suspension when they are submitted to a magnetic field gradient. ${ }^{25}$ Under steady-state conditions, the viscous force $(3 \pi \eta \mathrm{dV}$, where $\mathrm{V}$ is the cell velocity, $d$ the cell diameter, and $\eta$ the carrier medium viscosity) simply balances the magnetic force exerted on the cell $(\mathrm{M} \times \mathrm{dB} / \mathrm{dz}$, where $\mathrm{dB} / \mathrm{dz}=17 \mathrm{mT} / \mathrm{mm}$ is the magnetic field gradient, and $\mathrm{M}(\mathrm{B})$ is the cell magnetic moment in the field $\mathrm{B}=145 \mathrm{mT}$ ). After measuring the velocity and diameter for each cell, we can deduce the cell magnetic moment $\mathrm{M}=3 \pi \eta \mathrm{dV} /(\mathrm{dB} / \mathrm{dz})$ or equivalently the cell iron mass $\mathrm{m}_{\mathrm{Fe}}$ following the relationship $\mathrm{m}_{\mathrm{Fe}}(\mathrm{pg})=\mathrm{M} / 6 \times 10^{-14}$. For each condition of incubation, cell velocity and cell diameter were measured for 100 different cells, yielding the whole distribution of iron uptake in the cell population and giving access to the mean iron load \pm standard deviation.

Prussian blue staining was used to reveal the presence of intracellular iron directly after labeling procedure $(30 \mathrm{~min}$ incubation with extracellular iron concentration of $[\mathrm{Fe}]=$ $2 \mathrm{mM}$, followed by $1 \mathrm{~h}$ chase) and 7 days later. Labeled cells were fixed in $4 \%$ formaldehyde for $10 \mathrm{~min}$, washed and incubated for $20 \mathrm{~min}$ with $2 \%$ potassium ferrocyanide in 3.7\% hypochloric acid, washed again, and counterstained with nuclear fast red before observation.

Proliferation of MSCs was assessed by manually counting cells seeded into 6-well plates on days 1, 2, 4, and 7 after labeling procedure (30 $\mathrm{min}$ incubation with extracellular iron concentrations of $[\mathrm{Fe}]=2,5$, and $10 \mathrm{mM}$ ). Nonlabeled cells cultured in similar conditions served as controls. During proliferation, iron load per cell was quantified according to single-cell magnetophoresis, as described above, on days 0 , 3 , and 8 after labeling procedure $(30 \mathrm{~min}$ incubation with $[\mathrm{Fe}]=2 \mathrm{mM})$.

\section{Cell seeding in $3 D$ scaffolds}

The list of scaffolds, which have been imaged in vitro, is recapitulated in Table 1 with the corresponding MR acquisition parameters.

Freeze-dried lamellar scaffolds $(4 \mathrm{~mm}$ diameter, $3 \mathrm{~mm}$ thick) were seeded with $10 \mu \mathrm{L}$ of culture medium containing a fixed number of MSCs $\left(5 \times 10^{3}\right)$ labeled in different conditions $([\mathrm{Fe}]=0.05,0.2$, and $2 \mathrm{mM}$ for $30 \mathrm{~min})$ or containing different numbers of cells $\left(10^{3}, 5 \times 10^{3}\right.$, and $\left.20 \times 10^{3}\right)$ labeled with $[\mathrm{Fe}]=0.05 \mathrm{mM}$ for $30 \mathrm{~min}$. Nonlabeled cells were used as controls. The gels hydrated with cell suspension were then placed into the MRI containers described above and put for $5 \mathrm{~min}$ at $37^{\circ} \mathrm{C}$ in an atmosphere of $5 \% \mathrm{CO}_{2}$. One hundred $\mu \mathrm{L}$ of culture medium was then added to the hydrated gel in the container, and seeded gels were incubated for 4 days at $37^{\circ} \mathrm{C}$, $5 \% \mathrm{CO}_{2}$ before MRI. This time lapse allowed the removal of air bubbles from the scaffolds.
Porous globular scaffolds were allowed to equilibrate for $24 \mathrm{~h}$ in culture medium at $37^{\circ} \mathrm{C}$ before cell seeding. The cell suspension $\left(10 \mu \mathrm{L}\right.$ containing $20 \times 10^{3}$ cells labeled with $[\mathrm{Fe}]=2 \mathrm{mM}$ for $30 \mathrm{~min}$ ) was then seeded on the top of the gel in the container and seeded globular gels were cultured for 4 days as the lamellar scaffolds.

Scaffolds imaged in vivo are summarized in Table 2, with MR acquisition parameters. They consisted of freeze-dried lamellar scaffolds ( $3 \mathrm{~mm}$ diameter, $2 \mathrm{~mm}$ thick) seeded with $7 \mu \mathrm{L}$ of culture medium containing different numbers of cells $\left(7.5 \times 10^{3}\right.$ and $\left.37.5 \times 10^{3}\right)$ nonlabeled or labeled with $[\mathrm{Fe}]=0.2$ and $2 \mathrm{mM}$ for $30 \mathrm{~min}$. Scaffolds were incubated for 4 days at $37^{\circ} \mathrm{C}$ and checked for the absence of bubbles before in vivo implantation.

\section{Implantation of lamellar scaffolds in mice}

C57BL/6 mice were obtained from Elevage Janvier (l'Arbresle, France). All experiments complied with French legislation and guidelines for animal research. Mice were anesthetized by intraperitoneally injecting xylazine $2 \%$ (Rompun; Bayer, Leverkusen, Germany) and ketamine (Imalgene 500; Rhône Mérieux, Lyon, France) solution $(0.01 \mathrm{~mL}$ per $10 \mathrm{~g}$ of body weight, $4: 1 \mathrm{vol} / \mathrm{vol})$. Four mice were implanted subcutaneously after skin incision on the right posterior flank with two scaffolds side by side: one with control nonlabeled cells and the other with the same number of labeled cells and then imaged using high-resolution MRI (Table 2).

Mice 1, 2, and 3 were implanted with seeded scaffolds (Mouse $1,7.5 \times 10^{3}$ cells labeled with $[\mathrm{Fe}]=0$ and $2 \mathrm{mM}$; Mouse $2,37.5 \times 10^{3}$ cells labeled with $[\mathrm{Fe}]=0$ and $2 \mathrm{mM}$; Mouse $3,37.5 \times 10^{3}$ cells labeled with $[\mathrm{Fe}]=0$ and $0.2 \mathrm{mM}$ ). For the fourth mouse, the scaffold medium was changed for a $3 \mathrm{mM}$ gadolinium solution (Dotarem, Guerbet, France) before implantation to enhance the contrast (Mouse 4, $7.5 \times 10^{3}$ cells labeled with $[\mathrm{Fe}]=0$ and $0.2 \mathrm{mM}$ ).

\section{Magnetic resonance imaging}

MRI was performed on a 1.5-T clinical whole-body imaging system (Philips Achieva MR scanner) at the Centre Inter Etablissement Résonance Magnétique (Hôpital Bicêtre, France). A standard whole-body gradient system delivering an amplitude of $66 \mathrm{mT} / \mathrm{m}$ with a rise time of $800 \mu$ s was used.

The list of scaffolds imaged in vitro and acquisition parameters are summarized in Table 1.

Low-resolution MRI. To obtain a low-resolution standard of reference, three lamellar scaffolds were imaged using a commercial Philips $23 \mathrm{~mm}$ surface coil using a 2D spin echo sequence (echo time $(\mathrm{TE})=10,20,30,40,50 \mathrm{~ms}$, repetition time $(\mathrm{TR})=1000 \mathrm{~ms}$ ) and a 2D gradient echo sequence (flip angle $=90^{\circ}, \mathrm{TE}=10,20,30,40,50 \mathrm{~ms}, \mathrm{TR}=57 \mathrm{~ms}$ ). The three lamellar scaffolds were seeded with $5 \times 10^{3}$ nonlabeled cells, $5 \times 10^{3}$ cells labeled with $[\mathrm{Fe}]=0.2 \mathrm{mM}$, and $5 \times 10^{3}$ cells labeled with $[\mathrm{Fe}]=2 \mathrm{mM}$ and placed in a container $(8 \mathrm{~mm}$ outer diameter, $5 \mathrm{~mm}$ inner diameter, $6 \mathrm{~mm}$ height) filled with culture medium. In-plane resolution was $0.2 \times 0.28 \mathrm{~mm}^{2}$, and slice thickness was $3 \mathrm{~mm}$. Field of view was $20 \times 20 \mathrm{~mm}^{2}$. Signal intensity was measured using a region of interest placed on each scaffold. Relaxation rates R2 and R2* were obtained from fitting signal intensity versus echo time (for 


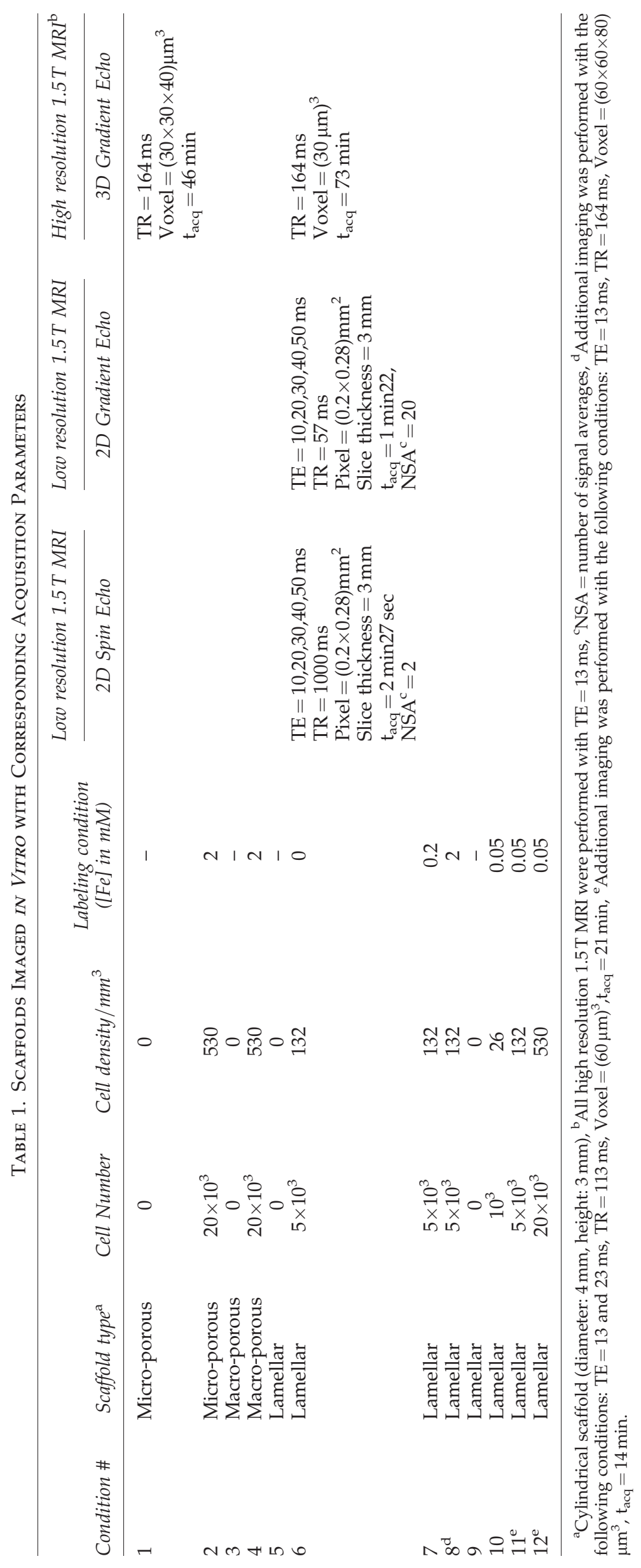


Table 2. in Vivo Experiments in Mice

\begin{tabular}{|c|c|c|c|c|c|}
\hline & $\begin{array}{l}\text { Number of seeded cells } \\
\text { in lamellar scaffold }\end{array}$ & Cell density $/ \mathrm{mm}^{3}$ & $\begin{array}{l}\text { Labeling condition } \\
\text { ([Fe] in } \mathrm{mM})\end{array}$ & $\begin{array}{l}\text { High resolution } 1.5 \mathrm{~T} \\
\text { MRI } 3 D \text { Gradient Echo }\end{array}$ & $\begin{array}{l}\text { Signal to noise ratio } \\
\text { (average } \pm S D)\end{array}$ \\
\hline \multirow[t]{2}{*}{ Mouse 1} & $7.5 \times 10^{3}$ & 530 & 0 & & $10.6 \pm 3.8$ \\
\hline & $7.5 \times 10^{3}$ & 530 & 2 & & $9.9 \pm 4.7$ \\
\hline \multirow[t]{2}{*}{ Mouse 2} & $37.5 \times 10^{3}$ & 2650 & 0 & $\begin{array}{l}\mathrm{TE}=13 \mathrm{~ms}, \mathrm{TR}=164 \mathrm{~ms} \\
\text { Voxel }=(60 \times 60 \times 80) \mu \mathrm{m}^{3} \\
\mathrm{t}_{\mathrm{acq}}=44 \mathrm{~min} \\
\text { Field of view }=(20 \times 20 \times 5) \mathrm{mm}^{3}\end{array}$ & $10.6 \pm 3.7$ \\
\hline & $37.5 \times 10^{3}$ & 2650 & 2 & & $4.1 \pm 3.9$ \\
\hline \multirow{2}{*}{ Mouse 3} & $37.5 \times 10^{3}$ & 2650 & 0 & & $8.1 \pm 3.1$ \\
\hline & $37.5 \times 10^{3}$ & 2650 & 0.2 & & $8.3 \pm 5.2$ \\
\hline \multirow[t]{2}{*}{ Mouse 4} & $7.5 \times 10^{3}$ (gadolinium) & 530 & 0 & & $101.9 \pm 16.7$ \\
\hline & $7.5 \times 10^{3}$ (gadolinium) & 530 & 0.2 & & $77.4 \pm 19.4$ \\
\hline
\end{tabular}

${ }^{a}$ Cylindrical scaffold (diameter: $3 \mathrm{~mm}$, height: $2 \mathrm{~mm}$ ).

Two lamellar scaffolds (one with nonlabeled cells, one with labeled cells) were implanted side by side subcutaneously in the lower flank of each mouse and imaged immediately after implantation. Signal to noise ratio (SNR) was averaged using regions of interest placed in the scaffold volume (7 slices, $\mathrm{n}=1)$. For comparison, $\mathrm{SNR}$ was $27.1 \pm 2.7$ in the adipose tissue $(\mathrm{n}=4)$ and $14.5 \pm 2.2$ in the surrounding muscle $(\mathrm{n}=4)$.

spin echo and gradient echo sequences respectively) using monoexponential dependence $(\exp (-\mathrm{R} 2 \times \mathrm{TE})($ resp. exp $\left.\left(-\mathrm{R} 2^{*} \times \mathrm{TE}\right)\right)$.

High-resolution MRI. High-resolution 3D MRI was performed using a 12-mm HTS surface coil cooled to $80 \mathrm{~K}$, as previously described. ${ }^{19}$ For all acquisitions, a 3D gradient-echo RF-spoiled sequence was used with a field of view of $6 \times 6 \times 3.5 \mathrm{~mm}^{3}$. Magnitude and phase of the MR signal were acquired simultaneously for all acquisitions. To enhance the contrast and assess architecture, the scaffold medium was changed $1 \mathrm{~h}$ before imaging for a $3 \mathrm{mM}$ gadolinium solution (Dotarem). The cylindrical container was then placed perpendicular to the HTS coil. The quality factor of the coil loaded by the hydrogel was 11,000 inside the magnet. MRI of scaffolds seeded with MSCs was done using the same protocol.

Architecture of the different scaffolds was visualized with a voxel size of $30 \times 30 \times 40 \mu \mathrm{m}^{3}$, a TR of $164 \mathrm{~ms}$, an TE of $13 \mathrm{~ms}$, a bandwidth (BW) of $36 \mathrm{~Hz} /$ pixel, and an average acquisition time ( $\mathrm{t}_{\mathrm{acq}}$ ) of $46 \mathrm{~min}$. To assess cell-seeding and cell-labeling influence in lamellar scaffolds, images were acquired using the isotropic resolution of $30 \mu \mathrm{m}^{3}$ (TR $=164 \mathrm{~ms}, \mathrm{TE}=13 \mathrm{~ms}$, $\mathrm{BW}=62 \mathrm{~Hz} /$ pixel and $\mathrm{t}_{\mathrm{acq}}=73 \mathrm{~min}$ ). To study the resolution effect, we compared acquisitions with voxel size of $60 \times 60 \times$ $80 \mu \mathrm{m}^{3} \quad\left(\mathrm{TR}=164 \mathrm{~ms}, \mathrm{TE}=13 \mathrm{~ms}, \mathrm{BW}=36 \mathrm{~Hz} /\right.$ pixel, $\mathrm{t}_{\mathrm{acq}}=$ $14 \mathrm{~min}$ ) and with isotropic resolution of $30 \mu^{3}(\mathrm{TR}=164 \mathrm{~ms}$, $\mathrm{TE}=13 \mathrm{~ms}, \mathrm{BW}=62 \mathrm{~Hz} /$ pixel, and $\mathrm{t}_{\mathrm{acq}}=73 \mathrm{~min}$ ). The echo time effect (TE $=13$ and $23 \mathrm{~ms}$ ) was studied using an isotropic resolution of $60 \mu \mathrm{m}^{3}(\mathrm{TR}=113 \mathrm{~ms}, \mathrm{BW}=103.5 \mathrm{~Hz}$ / pixel, $t_{\text {acq }}=21 \mathrm{~min}$ ). To assess cell distribution in different scaffold architectures, acquisitions were performed with a voxel size of $30 \times 30 \times 40 \mu \mathrm{m}^{3}$ (TR $=164 \mathrm{~ms}, \mathrm{TE}=13 \mathrm{~ms}, \mathrm{BW}=$ $72.8 \mathrm{~Hz} /$ pixel, and $t_{\text {acq }}=46 \mathrm{~min}$ ).

For in vivo observation of scaffolds, four mice were imaged immediately after implantation of two lamellar scaffolds side by side (one with nonlabeled MSCs, the other with labeled MSCs, Table 2) using the HTS coil and a 3D gradient echo sequence $(\mathrm{TE}=13 \mathrm{~ms}, \mathrm{TR}=164 \mathrm{~ms}$, field of view $=20 \times 20 \times$ $5 \mathrm{~mm}^{3}$, voxel size $=60 \times 60 \times 80 \mu \mathrm{m}^{3}, \mathrm{t}_{\mathrm{acq}}=44 \mathrm{~min}$ ) (Table 2).

The mice were held in a system equipped with a bed and positioned so as to maintain the right flank, where scaffolds were implanted, in contact with the HTS surface coil. The quality factor of the HTS coil loaded by the mouse was 4400 .

Image analysis. To analyze the orientation of grooves in the lamellar scaffold, angle measurements were performed using image treatment software Image by drawing lines parallel to such distinctive structures. The measure was repeated for approximately one out of 15 slices to avoid measuring the same structure twice. The orientational histogram has been obtained for sagittal and transverse planes for two different scaffolds.

For quantitative measurements of cell seeding, SNRs were extracted from magnitude images using the signal intensity (SI) measured in targeted volume of interest comprising seven consecutive slices (within scaffold, within carrier medium, or within surrounding structures in vivo (muscle or adipose tissue)), and the standard deviation $\left(\mathrm{SD}_{\text {noise }}\right)$ measured in the background noise. SNRs were displayed as (averaged $\mathrm{SI} \pm(\mathrm{SI} S \mathrm{SD})) / \mathrm{SD}_{\text {noise }}$

\section{Results}

High resolution MRI: noninvasive assessment of $3 D$ scaffold architecture.

Internal structures of scaffolds were imaged using the high-resolution HTS coil, achieving a resolution of $30 \times 30 \times$ $40 \mu^{3}$ (Table 1, conditions 1, 3, and 5). Scaffolds were infused with gadolinium solution to increase contrast with the medium. Architecture of the different scaffolds could be clearly distinguished on MR images (Fig. 1). The polysaccharide structure appears as regions of low signal intensity, with medium signal enhanced by gadolinium chelates.

MR images of microporous scaffolds (Fig. 1A) show a dense structure with quasispherical pores of small sizes mixed with some more-elongated grooves. Fluorescence microscopy evaluation of pore sizes leads to a mean pore size of $55 \pm 4 \mu \mathrm{m}$, and many pores could not be resolved using MRI. By contrast, macroporous scaffolds (Fig. 1B) present a foam-like structure made of large pores $(243 \pm 14 \mu \mathrm{m}$, using fluorescence microscopy). Evaluation of pore sizes from MR and fluorescence images could not be compared directly 
A
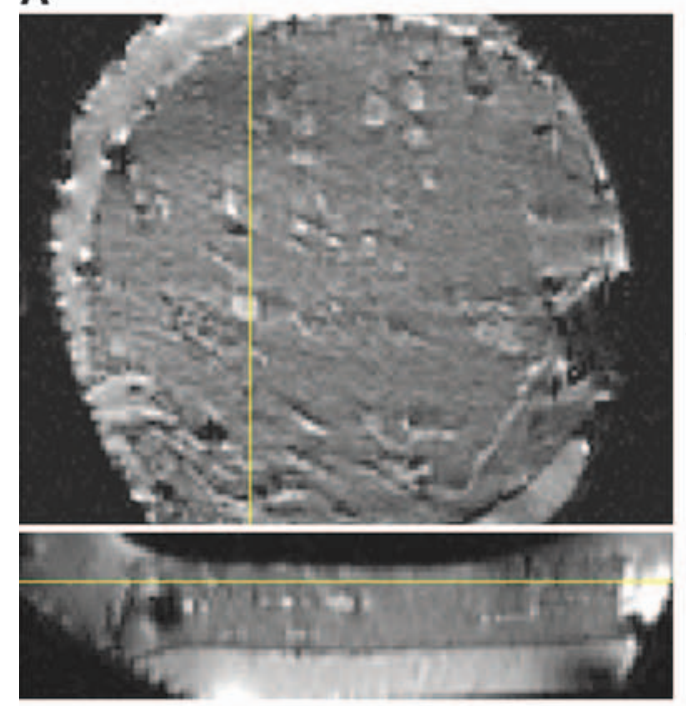

C

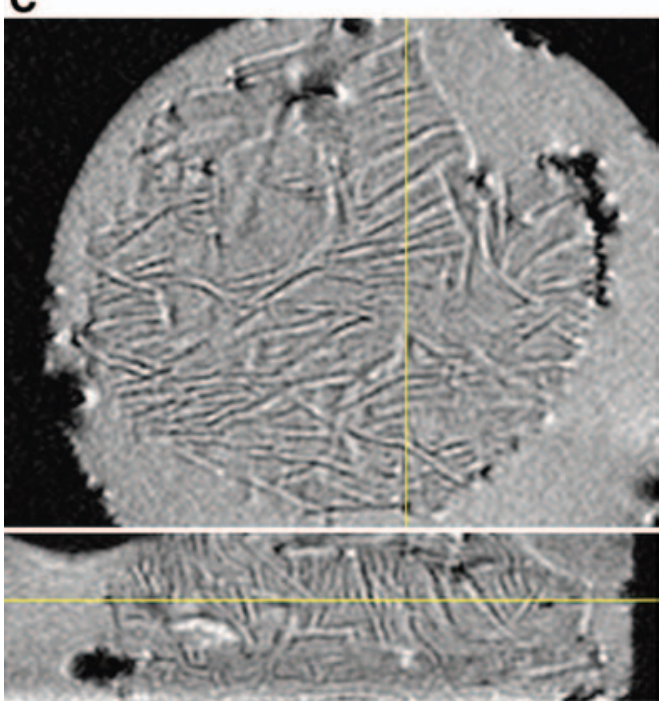

B

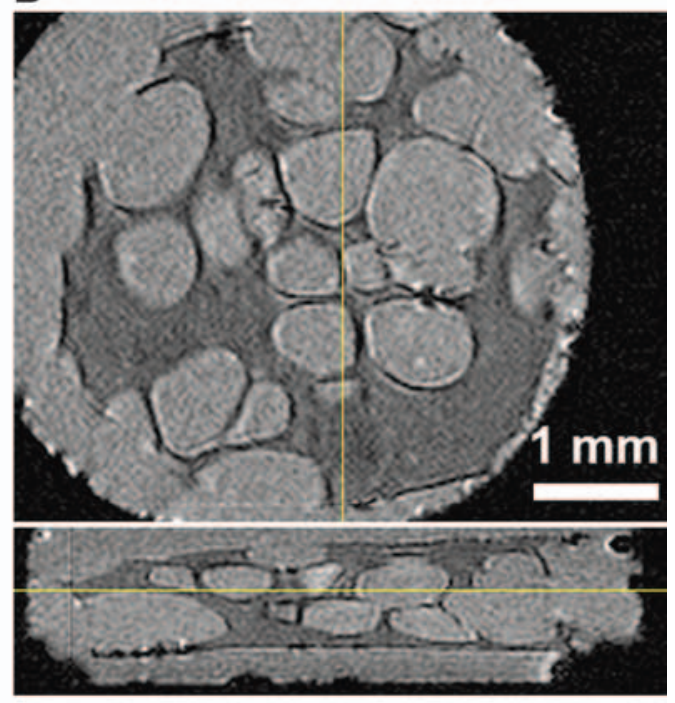

FIG. 1. High-resolution three-dimensional (3D) magnetic resonance imaging (MRI) of nonseeded hydrogel scaffolds with different internal structures. Transverse and longitudinal slices are shown. Slice location is marked by a line. Gadolinium-doped hydration medium is seen as areas of enhanced intensity, whereas areas of reduced intensity indicate the presence of structured scaffold. Black spots occasionally identified in nonseeded scaffolds correspond to remaining air bubbles. Acquisition time: $46 \mathrm{~min}$. Voxel size is $30 \times 30 \times 40 \mu^{3}$. Echo time $(\mathrm{TE})=13 \mathrm{~ms}$. (A) Microporous scaffold: MR image reveals porous architecture with small quasispherical cavities. (B) Macroporous scaffold: MR image shows a highly porous structure with large pores whose outlines are clearly visible. (C) Lamellar scaffold: MR image reveals a 3D lamellar structure. Because of their narrow width, trenches are identified as image artefacts showing parallel bright and dark outlines. Distribution of orientations and lengths of trenches can be seen clearly in the two plans shown.

because different samples were observed for each modality, and only one of each scaffold type (macro- and microporous) was observed using high-resolution MRI.

MR images of lamellar scaffolds show a different aspect with long anisotropic striations (Fig. 1C), which can be found

F2 on several successive MR slices (Fig. 2A, B). It indicates the presence of deep oriented grooves in the scaffold. Grooves could be observed via a susceptibility artefact, underlining the structure by parallel hypointense and hyperintense signals. Measurement of groove width on MR image is not reliable because of the extent of susceptibility artefact. The presence of deep trenches was confirmed using confocal microscopy of fluorescent scaffold (Fig. 2C), showing interconnected grooves with a mean width of less than $50 \mu \mathrm{m}$. The distribution of groove orientation could be deduced from MRI analysis of all sections, both in the longitudinal $\mathrm{x} 0 \mathrm{y}$ and transversal $\mathrm{x} 0 \mathrm{z}$ planes, as shown in Figure 2. Orientation histogram in the transversal plane shows a doublepeaked behavior (Fig. 2B), with a primary preferred direction centered at $-20^{\circ}$ from the vertical and a secondary preferred direction at $10^{\circ}$ to $20^{\circ}$ from horizontal. In the longitudinal sections (Fig. 2A), orientational distribution also presents a primary preferred direction centered at $20^{\circ}$. A single trench can span several consecutive transverse sections with strength up to $1 \mathrm{~mm}$.

\section{Magnetic labeling of MSCs}

Uptake of anionic maghemite nanoparticles by MSCs was quantified using single-cell magnetophoresis as a function of extracellular AMNP concentration during labeling (Fig. 3A). The tracking of 100 individual cells in movement at constant velocity toward a permanent magnet allows the magnetic moment and thus the iron load for each cell to be determined. Mean iron load per cell increased with AMNP concentration to a saturation value of $31 \pm 11 \mathrm{pg}$ of iron with only $30 \mathrm{~min}$ incubation time. A SD of more that $30 \%$ reflects the wide distribution of iron uptake within the cell population.

AMNP uptake for labeling iron concentration up to $10 \mathrm{mM}$ did not affect MSC proliferation up to 7 days after labeling (Fig. 3B). Iron load gradually decreased during proliferation, with a dilution rate that was consistent with the proliferation 
A
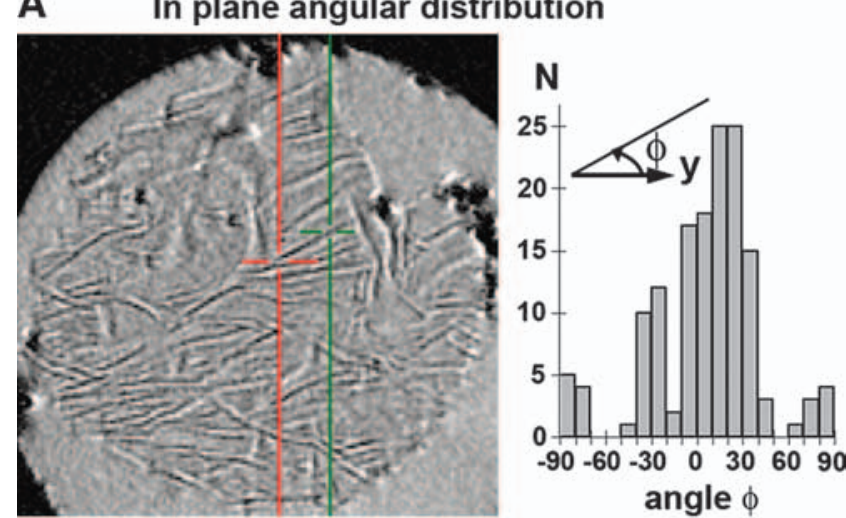

B

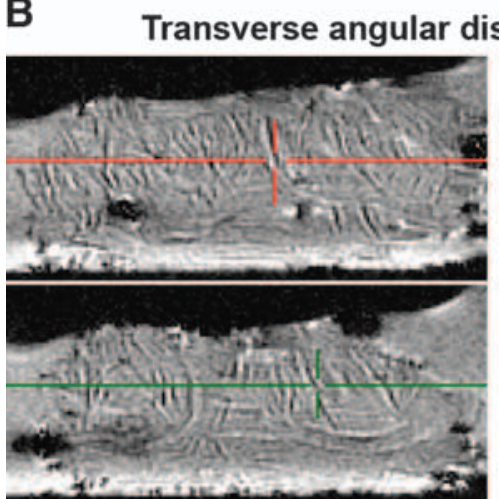

C

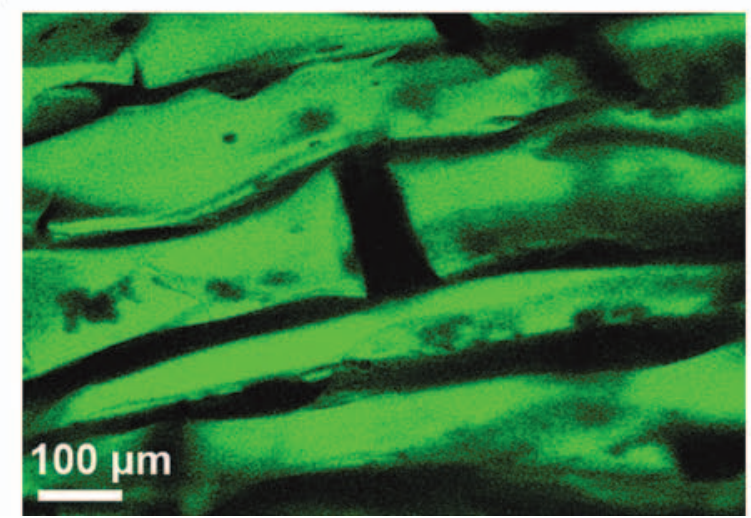

FIG. 2. Structural analysis of lamellar scaffolds. (a) Threedimensional MR assessment of lamella orientations in longitudinal plan $(\mathrm{x} 0 \mathrm{y})$. Trench orientation is defined by angle $\phi$ with y axis. Histogram of angle $\phi$ reveals primary preferred orientations at approximately $20^{\circ}$ and secondary preferred orientations at approximately $-30^{\circ}$. (b) Lamella orientations in transverse direction $(\mathrm{x} 0 \mathrm{z})$. Trenches orientation is defined by angle $\theta$ with $\mathrm{z}$ axis. Red and green lines indicates the relative locations of MR longitudinal (A) and transverse (B) slices in the gel. The same continuous trench can be observed on the longitudinal slice $\left(\phi=30^{\circ}\right)$ and on the two transverse slices $\left(\theta=-30^{\circ}\right)$. Transverse angular distribution peaked at approximately $\theta=-20^{\circ}$. Some lamellas oriented at approximately $\theta=-70^{\circ}$ are also observed. (c) Confocal imaging of fluorescein isothiocyanate-labeled scaffold. Optical horizontal slice was taken at a depth of $50 \mu \mathrm{m}$. Scale bar: $100 \mu \mathrm{m}$. Color images available online at www.liebertonline.com/ten.
A
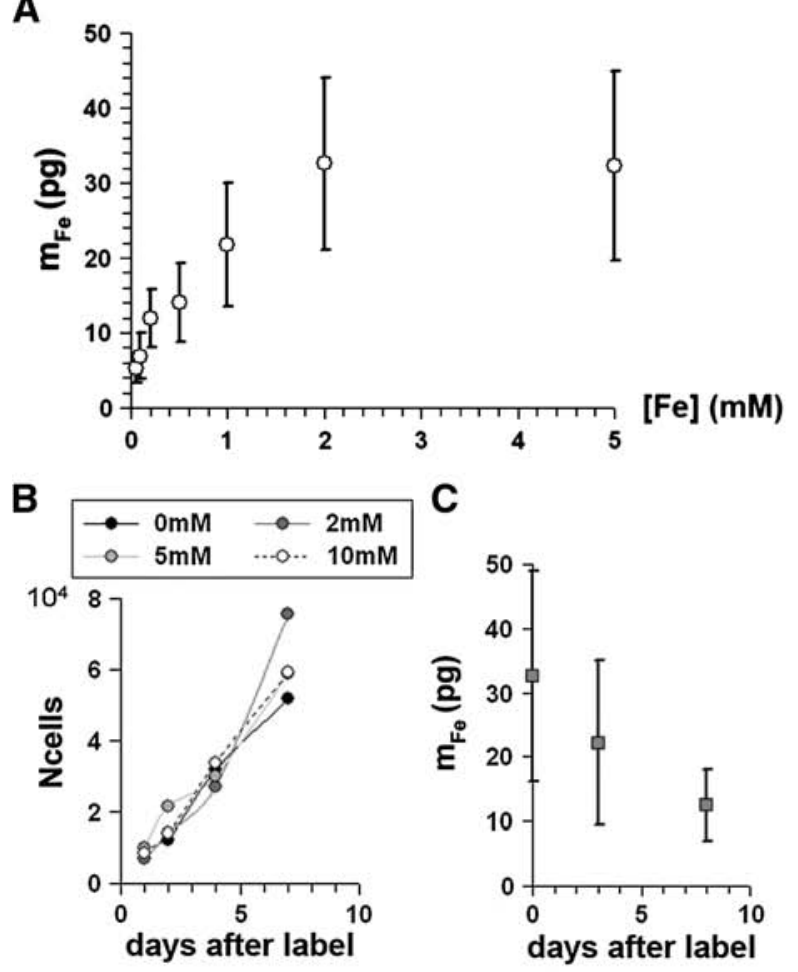

C
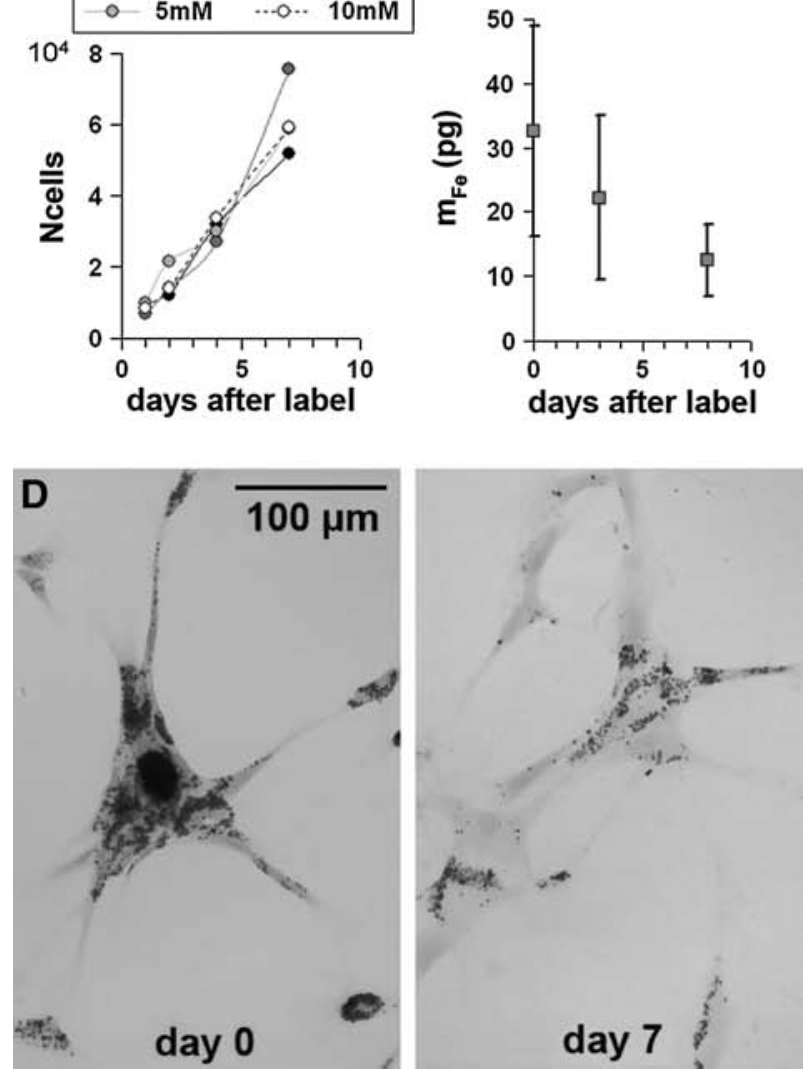

FIG. 3. Magnetic labeling of mesenchymal stem cells (MSCs): quantification and effect on cell proliferation. (A) Iron load per cell was quantified using single-cell magnetophoresis for 100 different cells for each extracellular iron concentration $[\mathrm{Fe}]$. Incubation time with anionic maghemite nanoparticles (AMNPs) was $30 \mathrm{~min}$. The mean iron load per cell $\mathrm{m}_{\mathrm{Fe}}$ (in pg) exhibits a saturable behavior as a function of extracellular iron concentration, with a maximum uptake of $31 \pm 11$ pg of iron per cell. Error bars represent the iron load dispersion within the cell population. (B) Cell proliferation was quantified up to 7 days for labeling conditions of $0,2,5$, and $10 \mathrm{mM}$. Cell number at each day normalized to the initial cell number shows no difference as a function of magnetic labeling. (C) Cell iron load was quantified during proliferation; the rate of dilution of magnetic content was roughly proportional to proliferation rate. (labeling condition $[\mathrm{Fe}]=2 \mathrm{mM}$ for $30 \mathrm{~min}$ ). (D) Perls staining of magnetically labeled MSCs at day 0 and day 7 after labeling (labeling condition $[\mathrm{Fe}]=2 \mathrm{mM}$ for $30 \mathrm{~min}$ ). Color images available online at www.liebertonline.com/ten. 
rate and absence of exocytosis process (Fig. 3C). Dilution of intracellular nanoparticles by cell division could also be observed using Prussian blue staining, revealing less-intense blue color at day 7 after labeling (Fig. 3D).

\section{Low resolution MRI: influence of cell seeding}

As a reference, we performed low-resolution MRI on three lamellar scaffolds seeded with MSCs with increasing iron

F4 load (Fig. 4). For this purpose, we used a standard 23-mm Philips surface coil instead of the high-resolution HTS detection coil on the clinical 1.5-T device. Two-dimensional spin echo and gradient echo sequences were performed (Table 1, conditions 6, 7, and 8). As expected, the lamellar structure of scaffolds could not be observed at low resolution (in-plane resolution of $0.2 \times 0.28 \mathrm{~mm}^{2}$ and slice thickness of $3 \mathrm{~mm}$ ), although the seeding of scaffolds with $5 \times 10^{3}$ magnetically labeled cells created an overall negative signal

\section{Spin echo (TE=10ms)}
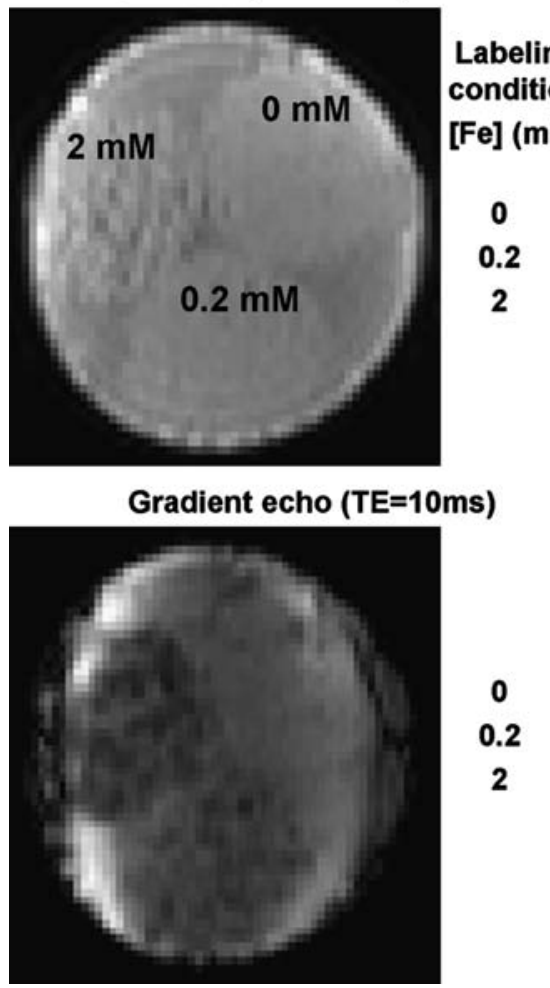

FIG. 4. Low-resolution imaging of cell seeding on lamellar scaffold: Influence of cell labeling condition. Number of seeded cells in lamellar scaffold was $5 \times 10^{3}$. Iron concentration $[\mathrm{Fe}]$ during labeling was 0 (control cells), 0.2 , and $2 \mathrm{mM}$. Scaffolds were imaged using a standard Philips 23-mm surface coil using a 2D spin echo sequence and a 2D gradient echo sequence with various TE. In-plane resolution was $0.2 \times 0.28 \mathrm{~mm}^{2}$, and slice thickness was $3 \mathrm{~mm}$. Relaxation rates $\mathrm{R} 2$ and $\mathrm{R} 2{ }^{*}$ were obtained from fitting signal intensity versus echo time (for spin echo and gradient echo sequences, respectively) using monoexponential dependence (exp(-R2 $\times$ TE) (resp. $\left.\exp \left(-\mathrm{R} 2^{*} \times \mathrm{TE}\right)\right) \cdot \mathrm{r}^{2}$ is the square of correlation coefficient between experimental data values and theoretical fit. Upper (resp. lower) view represents the three scaffolds imaged using respectively spin echo and gradient echo sequence with $\mathrm{TE}=13 \mathrm{~ms}$. contrast with respect to the control scaffold with nonlabeled cells. It was possible to distinguish scaffolds containing cells with different iron load (12 and $31 \mathrm{pg}$ of iron/cell for labeling condition of $[\mathrm{Fe}]=0.2$ and $2 \mathrm{mM}$, respectively). Contrast between scaffolds increased with echo time. Monoexpon-

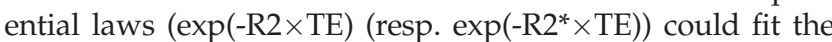
dependence of signal intensity versus echo time for spin echo and gradient echo acquisition, yielding the relaxation rates R2 and R2* for the three scaffolds (Fig. 4).

Taking the relaxation rate of the control scaffold as reference $(\mathrm{R} 2(0 \mathrm{mM})=1.4 / \mathrm{s})$, we can estimate the change in transversal relaxation rate due to the labeled cells, which was found to be $\mathrm{R} 2(2 \mathrm{mM})-\mathrm{R} 2(0 \mathrm{mM})=1.5 / \mathrm{s}$ and $\mathrm{R} 2(0.2 \mathrm{mM})$ $\mathrm{R} 2(0 \mathrm{mM})=0.5 / \mathrm{s}$ for the $[\mathrm{Fe}]=2$ and $0.2 \mathrm{mM}$ labeling conditions, respectively. As expected, this change was directly proportional to the global iron concentration in the scaffold or equivalent to the iron load per cell, the number of seeded cells being constant. The same proportionality with iron content is verified for the increase in relaxation rate, $\mathrm{R} 2 *$ which appears to be two orders of magnitude larger than change in R2. It is consistent with the fact that the gradient echo sequence is more sensitive to the presence of labeled cells than the spin echo sequence.

\section{High-resolution MRI: 3D assessment of cell seeding}

Increasing MRI resolution allows imaging the spatial distribution of labeled cells. An isolated labeled cell, dispersed in agarose gel, appears as a punctual signal void on highresolution images acquired using a 3D gradient echo sequence. The corresponding phase image shows a characteristic phase distortion due to the local magnetic field created by the magnetized cell. The volume of signal loss associated with a single cell largely exceeds its physical size and increases with cell iron load and with echo time, which is the time during which surrounding protons will experience the local field. Detectability of single-labeled cells depends on the spatial resolution achieved..$^{15,26}$

The relevant parameters for detection of labeled cells were investigated here for MSCs seeded on scaffolds with complex architecture, in particular the polysaccharide lamellar scaffolds (Table 1, conditions 6 to 12).

As shown in Figure 5, labeled cells seeded at a density of 132 cells $/ \mathrm{mm}^{3}\left(5 \times 10^{3}\right.$ cells) are seen as signal voids unevenly distributed within the gel. Nonlabeled cells are not seen within the lamellar scaffold, whereas very large signal voids signalled MSCs labeled with $31 \mathrm{pg}$ of iron (labeling condition of $[\mathrm{Fe}]=2 \mathrm{mM}$ ). Lower labeling (5 pg and $12 \mathrm{pg}$ of iron/cell, corresponding to labeling conditions of $[\mathrm{Fe}]=0.05$ and 0.2 $\mathrm{mM}$, respectively) allows better observation of cell distribution, which can be distinguished together with the scaffold architecture. Overall, the SNR of the scaffold decreased with increasing labeling efficiency: SNR $(0 \mathrm{mM})=13.6 \pm 3.4$, SNR $(0.05 \mathrm{mM})=11.4 \pm 3.8, \quad$ SNR $\quad(0.2 \mathrm{mM})=10.1 \pm 4.4, \quad$ SNR $(2 \mathrm{mM})=8.3 \pm 5.3$ (Fig. 5).

Degrading resolution from $30 \times 30 \times 40 \mu^{3}$ to $60 \times 60 \times 80 \mu \mathrm{m}^{3}$ resulted in less-accurate assessment of cell distribution (Fig. 6A).

The SNR loss due to labeled cells, relative to the carrier medium, increased with echo time, being $-39 \%$ for $\mathrm{TE}=$ $13 \mathrm{~ms}$ and $-51 \%$ for $\mathrm{TE}=23 \mathrm{~ms}$ (Fig. 6B). Nevertheless, cell organization was better resolved using an echo time of $13 \mathrm{~ms}$ rather than $23 \mathrm{~ms}$, because signal voids created by the labeled 
Influence of labeling condition
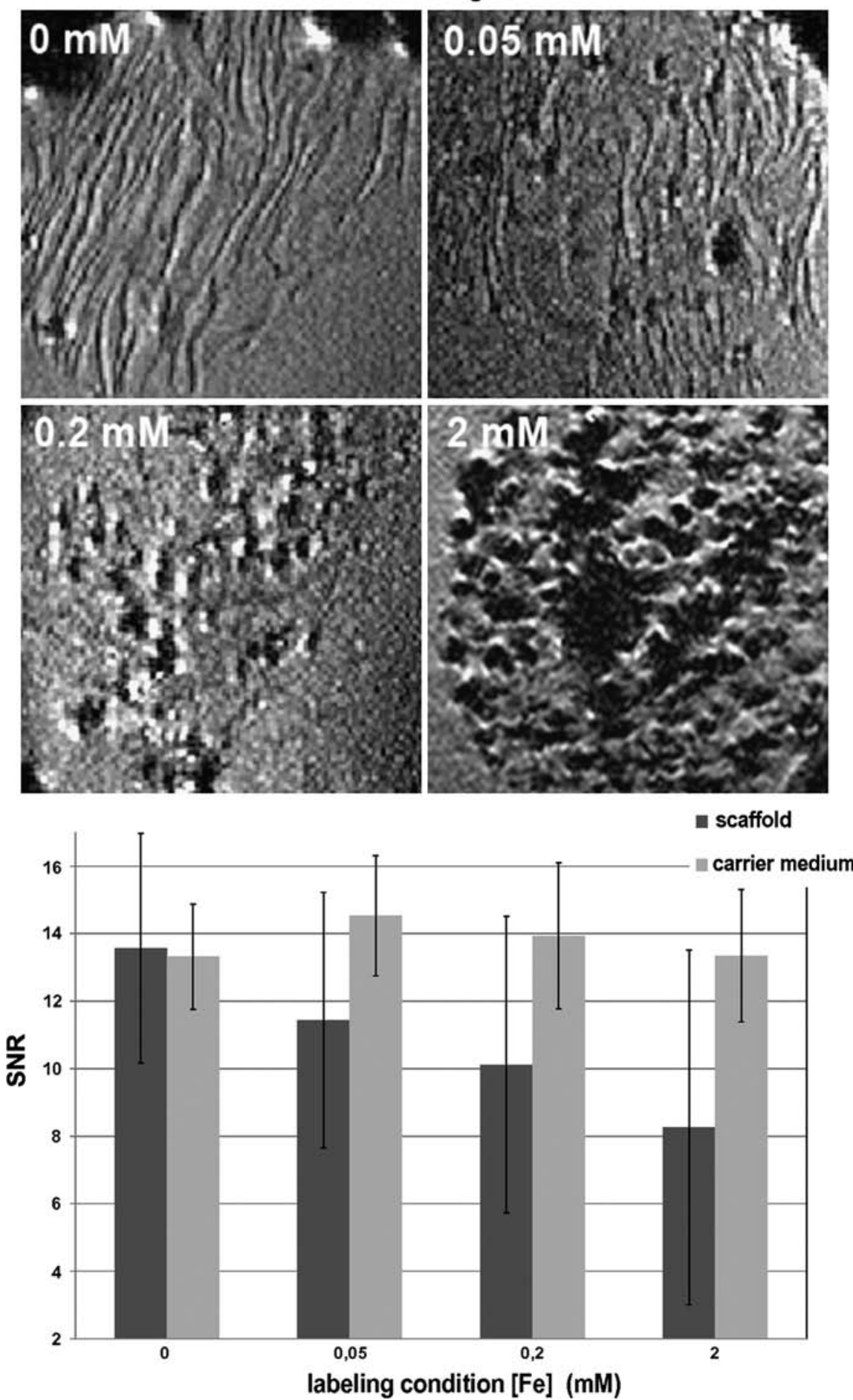

FIG. 5. High-resolution imaging of cell seeding on lamellar scaffold: Influence of cell labeling condition. Extracellular iron concentration [Fe] ranged from 0 (control nonlabeled cells) to $2 \mathrm{mM}$. Number of seeded cells in lamellar scaffold was $5 \times 10^{3}$. Areas of reduced signal intensity (black spots) indicate the presence of labeled cells. Black spots become larger with increasing cell iron load. Voxel size is $30 \times 30 \times 30 \mu \mathrm{m}^{3}$.

$\mathrm{TE}=13 \mathrm{~ms}$. Graph displays the averaged signal to noise ratios (SNRs) in the scaffold and in the carrier medium as a function of celllabeling condition. Error bars represent the SNR standard deviation in the volume of interest. cells were smaller. Thus, imaging cell distribution requires a compromise between sensitivity to cell magnetization (enhanced with cell iron load and with echo time) and spatial accuracy (degraded by increasing echo time, cell iron load, and voxel size).

When cell seeding density was increased (from 26 to 530 cells $/ \mathrm{mm}^{3}$ : Table 1 , conditions 10,11 , and 12$)$, morenumerous and larger signal voids were detected in the

F7 scaffold (Fig. 7). Signal voids corresponded to characteristic phase distortions on the phase image (Fig. 7, inset). Quanti- tatively, overall SNR decreased with increasing cell number: SNR $(0$ cells $)=13.5 \pm 3.3$, SNR $(1000$ cells $)=13.3 \pm 3.3$, SNR $(5000$ cells $)=11.5 \pm 3.7$, SNR $(20000$ cells $)=10.8 \pm 5.0$. The SNR standard deviation increased with cell density.

High-resolution MRI reveals different cell distribution depending on scaffold internal structure

To assess the relationship between scaffold architecture and cell distribution, magnetically labeled MSCs were 
A

FIG. 6. Imaging cell seeding on lamellar scaffold: role of acquisition parameters. (A) Influence of image resolution. Left: Voxel si$\mathrm{ze}=60 \times 60 \times 80 \mu^{3}$. Right: Voxel size $=30 \times 30 \times 30 \mu^{3}$. Number of seeded cells is $5 \times 10^{3}$ (top) and $20 \times 10^{3}$ (bottom), and labeling condition is $[\mathrm{Fe}]=0.05 \mathrm{mM}$. TE $=13 \mathrm{~ms}$. (B) Influence of echo time. Left: $\mathrm{TE}=13 \mathrm{~ms}$, Right: $\mathrm{TE}=23 \mathrm{~ms}$. Increasing echo time amplifies the size of signal void due to a labeled cell. Number of seeded cells is $5 \times 10^{3}$. Labeling condition is $[\mathrm{Fe}]=2 \mathrm{mM}$. Voxel size: $60 \times 60 \times 60 \mu \mathrm{m}^{3}$.
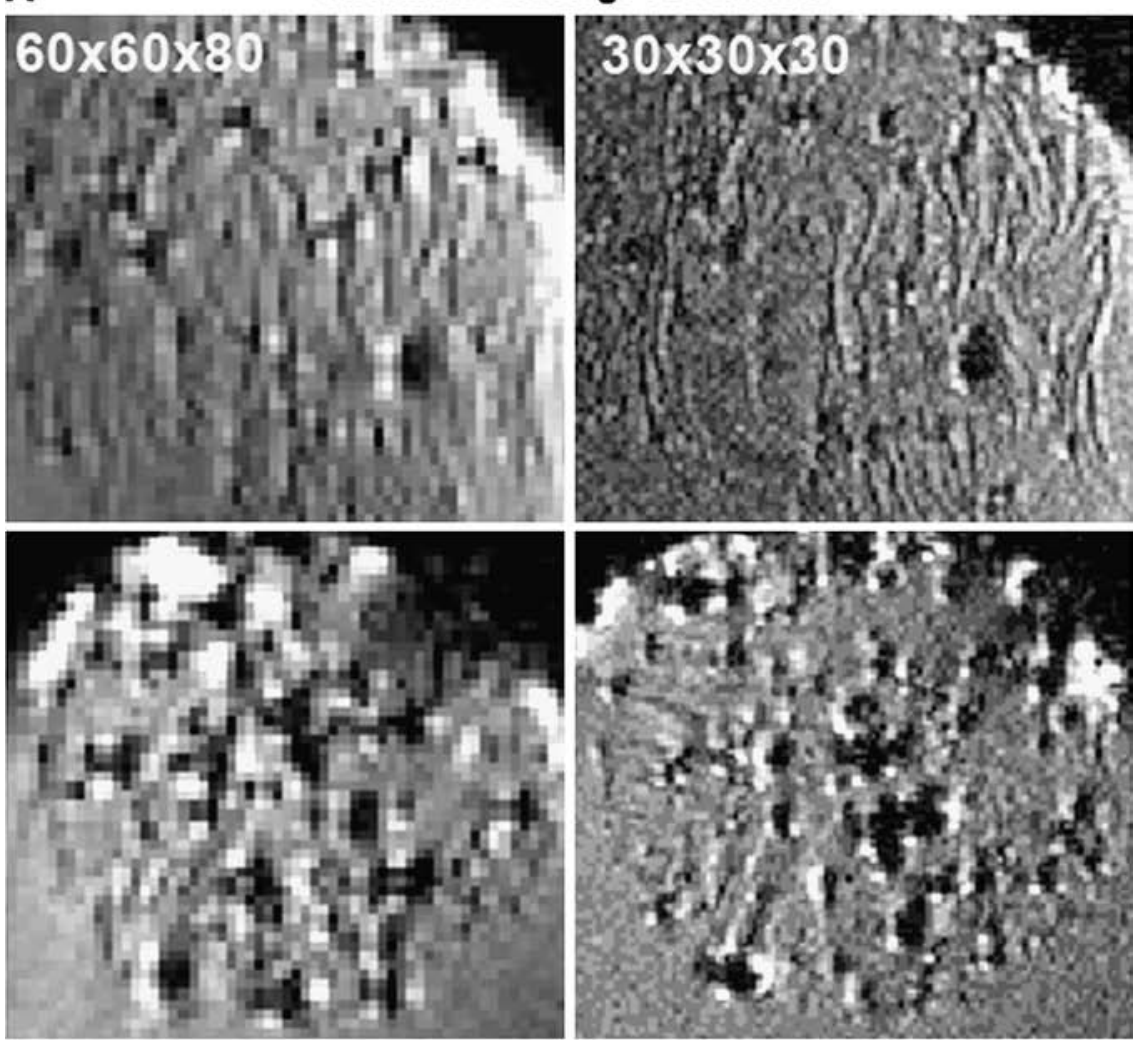

B
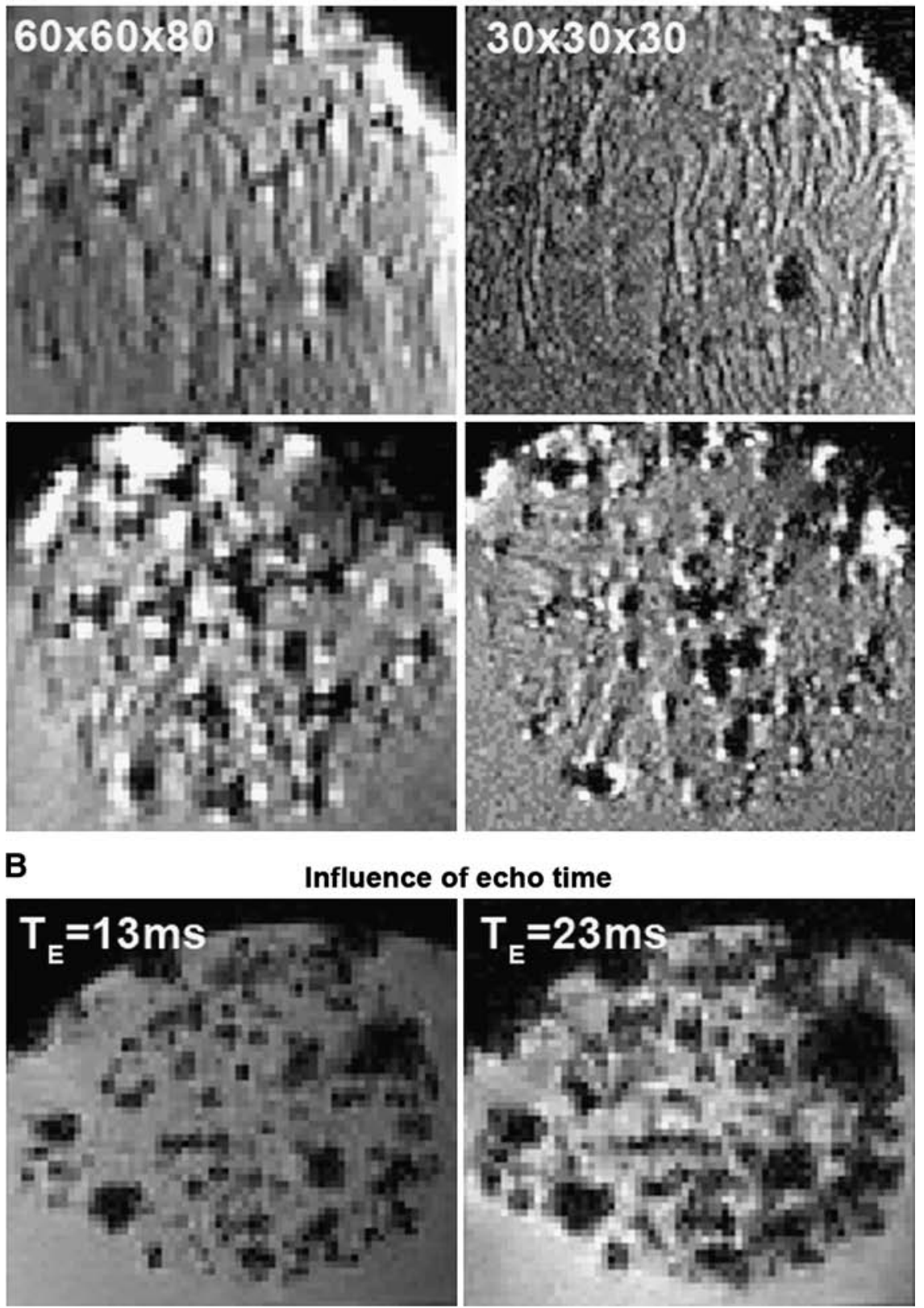

Influence of echo time

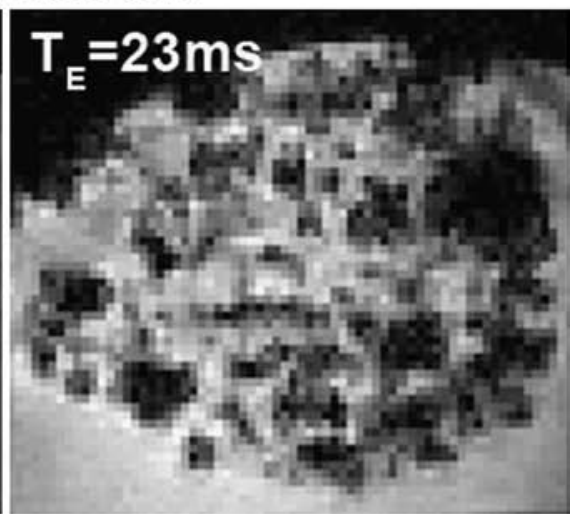

seeded on the different scaffolds (Table 1 , conditions 2,4 , and

F8 8). As shown in Figure 8, cell organization was strongly dependent on scaffold structure. The microporous scaffold showed uneven infiltration of cells, with most cells on the top and side of the scaffold (Fig. 8A). The macroporous scaffold allowed penetration of cells within the structure, but a small number of cells was observed and mainly on the wall of very large pores (Fig. 8B). By contrast, cells homogeneously infiltrated the whole volume of the lamellar scaffold (Fig. 8C).

\section{High-resolution MRI of lamellar scaffolds in vivo}

1.5-T MRI combined with HTS coil was tested in vivo for imaging scaffolds seeded with MSCs and implanted subcutaneously in mice (Table 2). A resolution of $60 \times 60 \times 80 \mu \mathrm{m}^{3}$ was achieved for an acquisition time of $44 \mathrm{~min}$ and a field of view of $20 \times 20 \times 5 \mathrm{~mm}^{3}$. Compared with imaging conditions in vitro, a SNR loss of a factor of 2.5 was estimated in vivo.

Two lamellar scaffolds were implanted side by side in each mouse: one control scaffold containing nonlabeled cells and the other containing labeled cells. As shown in Figure 9, both scaffolds could be readily located on sagittal slices and distinguished from subcutaneous adipose tissue, which appears as a hypersignal area. SNR in adipose tissue was close for all mice, with an average value of $27.1 \pm 2.7(n=4)$. The spatial resolution allowed the vessels in adipose structures to be observed. Control scaffolds showed a homogeneous signal, with a SNR of $10.6 \pm 3.6$ in Mouse 1, $10.6 \pm 3.7$ in Mouse 2 , and $8.1 \pm 3.7$ in Mouse 3. By contrast, a highly heterogeneous signal could be observed within scaffolds containing labeled cells, consistent with in vitro observations. The SNR decreased with increasing cell density or cell iron load (Table 
2); it was found to be $9.9 \pm 4.7$ in Mouse 1 (density of 530 cells $/ \mathrm{mm}^{3}$ labeled with $\left.[\mathrm{Fe}]=2 \mathrm{mM}\right), 4.1 \pm 3.9$ in Mouse 2 (density of 2650 cells $/ \mathrm{mm}^{3}$ labeled with $[\mathrm{Fe}]=2 \mathrm{mM}$ ), and $8.3 \pm 5.2$ in Mouse 3 (density of 2650 cells $/ \mathrm{mm}^{3}$ labeled with $[\mathrm{Fe}]=0.2 \mathrm{mM})$.

Phase images reveal the presence and density of labeled cells by rapidly varying punctual phase distortions (from $-\pi$ to $\pi$ ). By contrast, control scaffolds and surrounding tissue structures show phase profiles, which slowly vary because of localization gradient.

Two scaffolds previously immersed in gadolinium solution (as for in vitro high-resolution study) were implanted in Mouse 4. They appear as areas of greater hypersignal than adipose tissue and muscle (image not shown). Signal heterogeneities can be found in the control scaffold, partially revealing its lamellar structure $(\mathrm{SNR}=101.9 \pm 16.7)$. The scaffold with labeled cells (density of 530 cells $/ \mathrm{mm}^{3}$ labeled with $[\mathrm{Fe}]=0.2 \mathrm{mM}$ ) shows a highly heterogeneous signal, with an SNR of $77.4 \pm 19.4$.

\section{Discussion}

We show in this article that high-resolution MRI performed on a clinical 1.5-T MRI device can be effective in visualizing hydrogel scaffolds with complex architecture and characterizing cell seeding on these scaffolds in vitro and in vivo. Our approach to increase spatial resolution while operating on a clinical 1.5-T MRI was to use a high-temperature superconducting yttrium barium copper oxide detection coil with low noise. ${ }^{27}$ Thanks to a gain in SNR of a factor of 10 compared with conventional room-temperature copper coil, we achieved unprecedented spatial resolutions of $30 \mu \mathrm{m}^{3}$ for acquisition time of approximately $1 \mathrm{~h}$. This methodology challenges the use of high-field MRI ${ }^{28-30}$ to enhance resolution and overcomes some limitations of high-field technology such as cost, poor availability, susceptibility artefact, and reduced bore. Moreover, the high-field approach is not clinically applicable because most clinical MR units have a field strength between $0.5 \mathrm{~T}$ and $3 \mathrm{~T}$.

A first objective was to evaluate high-resolution MRI for assessment of the internal structure of polysaccharide scaffolds. The contrast to noise ratio between the polymer structure and the liquid phase was enhanced using a gadolinium solution, a T1 contrast agent, which increases the signal of the liquid phase. The internal architecture of the scaffold was then directly observed, revealing 3D organizations, depending on the method of fabrication. The crosslinking of polysaccharides during the freeze-drying process allowed almost spherical pores to be produced in the polymeric matrix, with different sizes depending on the freezedrying pressure. ${ }^{23}$ Lamellar scaffolds were also obtained from the same polysaccharides using a gas-foaming technique. ${ }^{24}$ MRI analysis revealed deep grooves on the scaffolds, appearing on successive slices in transverse and longitudinal directions. One preferential orientation tilted from the vertical was found, and some transversal trenches were also observed at $10^{\circ}$ to $20^{\circ}$ from the horizontal. The peculiar anisotropy of these lamellar scaffolds is probably determined during the gas-foaming process. It should permit adequate diffusion of nutrient and gas through the scaffold layers and promote cell seeding and organization. Although MRI was effective in evaluating the 3D anisotropy of the scaffold, spatial resolution was not sufficient to resolve trench width. In comparison with optical imaging, noninvasive MRI brings complementary information on the internal structure of complex scaffold and as such should participate in the characterization of new scaffold design. ${ }^{2}$

The second objective was to characterize, using MRI, the stem cell distribution in the scaffolds after the seeding procedure. To make it detectable by MRI, MSCs were labeled with anionic iron oxide nanoparticles, a T2 contrast agent inducing negative contrast at the place of the cell. MRI of cells magnetically labeled before transplantation has been demonstrated recently as a method of choice to monitor cell migration noninvasively and repeatedly. Several groups have shown that therapeutic cells, including stem cells, could be safely labeled with iron oxide nanoparticles and further visualized using MRI, allowing in vivo cell tracking after local implantation or intravenous injection ${ }^{6-9}$ or associated with engineered scaffolds. $^{16,17,31,32}$ In this study, MSCs were labeled with citratecoated maghemite nanoparticles, which have been proven to be an efficient contrast agent to tag a wide variety of cells without impairing their proliferation and functionalities. ${ }^{22}$ The labeling procedure is simple and rapid because negatively charged nanoparticles adsorb nonspecifically on the cell membrane, triggering internalization via an endocytosis pathway. Surface properties have previously been found to influence cellular uptake, the ionic coating being the most effective for cell labeling by simple incubation. ${ }^{33,34}$ In contrast to the labeling procedure involving dextran-coated nanoparticles (superparamagnetic iron oxides, ultrasmall superparamagnetic iron oxides), ${ }^{35,36}$ less than $1 \mathrm{~h}$ of incubation with citrate-coated nanoparticles is sufficient to promote cell internalization at a high rate. ${ }^{37}$ MSCs internalized approximately $30 \mathrm{pg}$ of iron after only $30 \mathrm{~min}$ of incubation with $2 \mathrm{mM}$ of extracellular iron. This high uptake is linked to the large size of cells. The number of AMNPs that may adsorb on the plasma membrane is proportional to the membrane surface, as demonstrated recently using cell lines of various sizes. ${ }^{22}$ Intracellular iron load did not inhibit cell proliferation, which was similar to control unlabeled cells, even for labeling conditions of up to $10 \mathrm{mM}$. As previously shown for other cell lines, daughter cells shared the particle load during cell division.

MSCs have differentiation potential toward diverse cell types such as adipogenic, osteogenic, and chondrogenic lineages. ${ }^{38}$ Myogenic differentiation of MSCs has also been described. ${ }^{39}$ A key issue is thus to verify that magnetic labeling does not affect differentiation capacity. This concern was debated recently, especially the chondrogenic differentiation. ${ }^{35,40,41}$ Using commercially available citrate-coated nanoparticles (VSOPs C200, Ferropharm, Teltow, Germany), Heymer et al. did not find any adverse influence of labeling on the differentiation of MSCs in adipocytes, osteocytes, and chondrocytes for a labeling condition leading to $4.6 \mathrm{pg}$ of iron per cell. ${ }^{17}$ Further studies are in progress in our laboratory to study the effect of AMNPs on MSC differentiation for different labeling conditions.

MRI detection of AMNP-labeled cells has been proven previously in vitro and in vivo. Detection at the single cell level could be achieved in agarose gels using high resolution provided by a 9.4-T MRI device ${ }^{26}$ or on a clinical 1.5-T unit equipped with the presently used HTS detection coil. ${ }^{15}$ Cells loaded with superparamagnetic nanoparticles act as a strong and local magnetic perturbation for the surrounding protons; 
FIG. 7. Assessment of cell density in lamellar scaffold. AMNP-labeled MSCs were seeded in lamellar scaffold at different cell densities: control nonseeded scaffold, $10^{3}, 5 \times 10^{3}$, and $20 \times 10^{3}$ seeded cells. Labeling condition was $[\mathrm{Fe}]=0.05 \mathrm{mM}$. Voxel size is $30 \times 30 \times 30 \mu \mathrm{m}^{3}$. TE $=13 \mathrm{~ms}$. Spots of hypointense signal are more numerous and larger with increasing density of cell seeding. Insert on top right represents the MR phase signal corresponding to the modulus signal in the underlined rectangle. Hypointense signals corresponding to the presence of cells appear as phase defects in the phase image. Graph displays the averaged SNRs in the scaffold and in the carrier medium as a function of seeded cell number. Error bars represents the SNR standard deviation in the volume of interest.

\section{Influence of cell density}

No cells

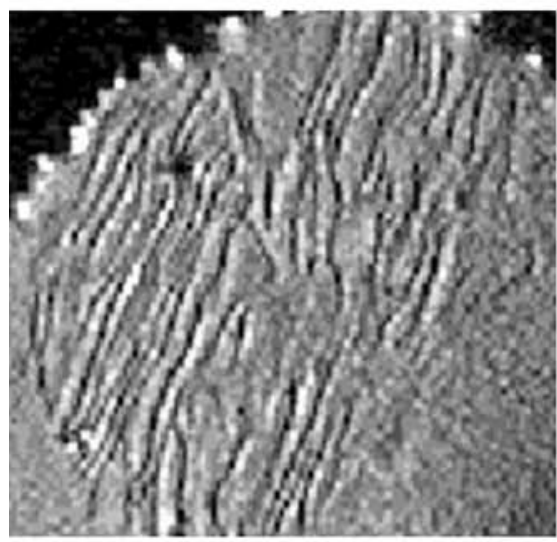

5000

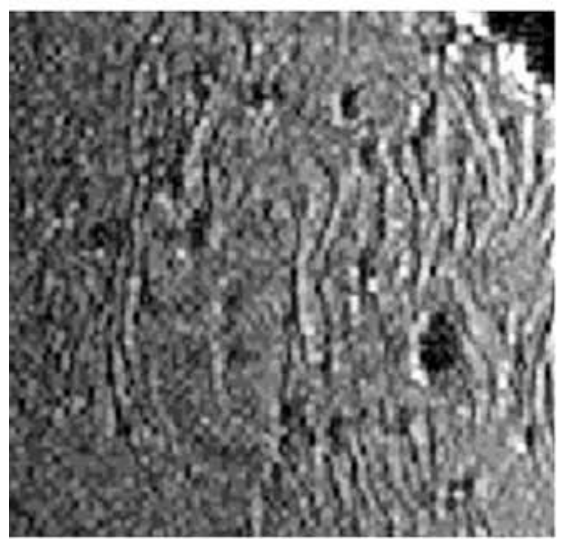

1000
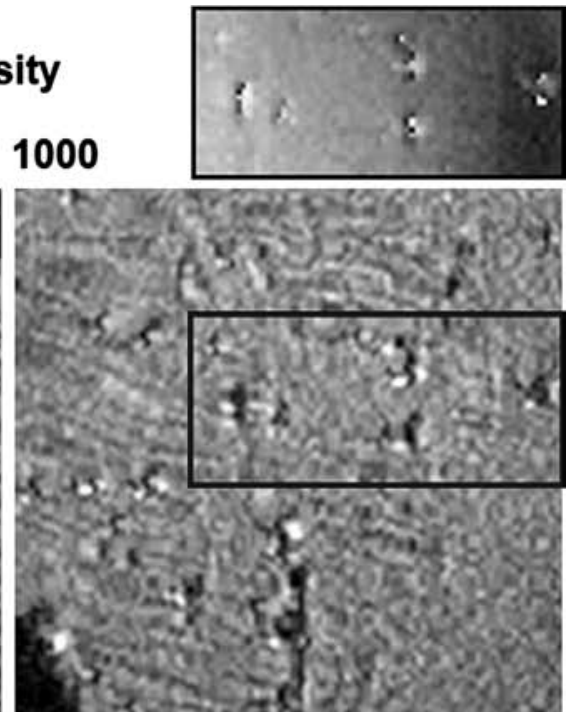

20000 cells
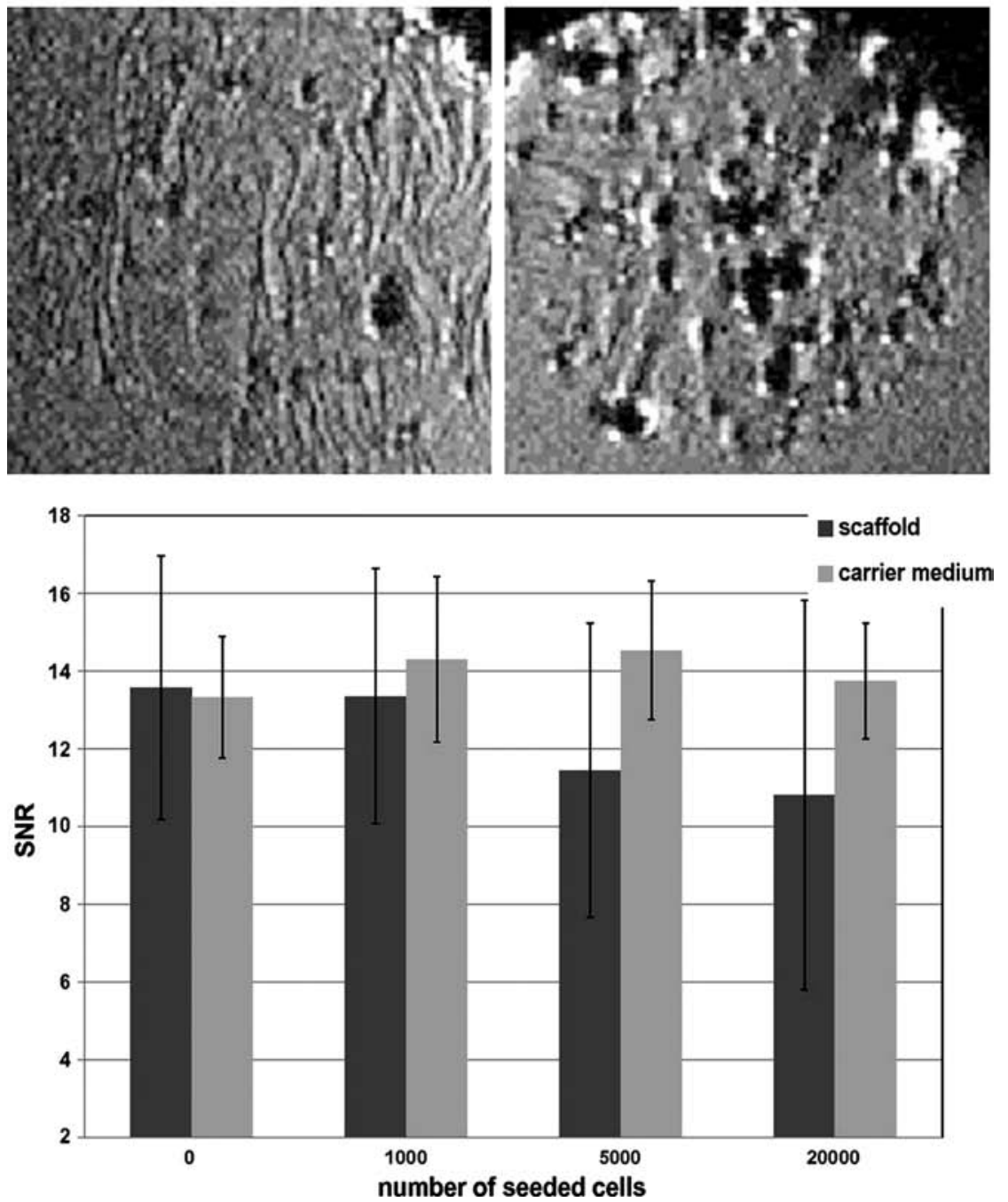

phase-lag of proton magnetizations results in a signal loss around the cell. This so-called $\mathrm{T} 2 *$ effect is accurately detected using gradient echo sequence and is amplified by nanoparticle confinement inside intracellular endosomes.
Magnetic cells appear thus as signal voids whose size increases with cell magnetization and echo time and exceeds the actual size of the cell. ${ }^{26,42}$ Typically a voxel size of less than $100 \mu \mathrm{m}$ is needed for detection of single individual cells. 
A

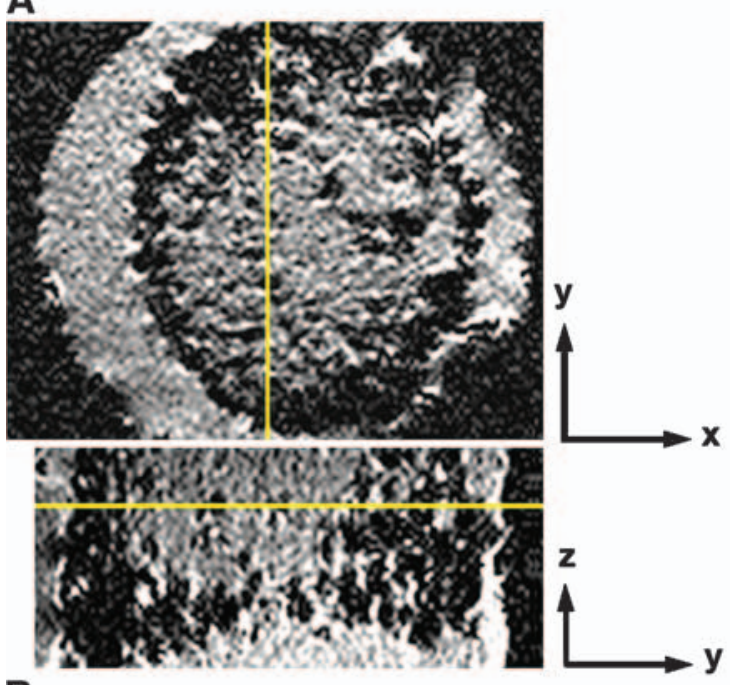

B
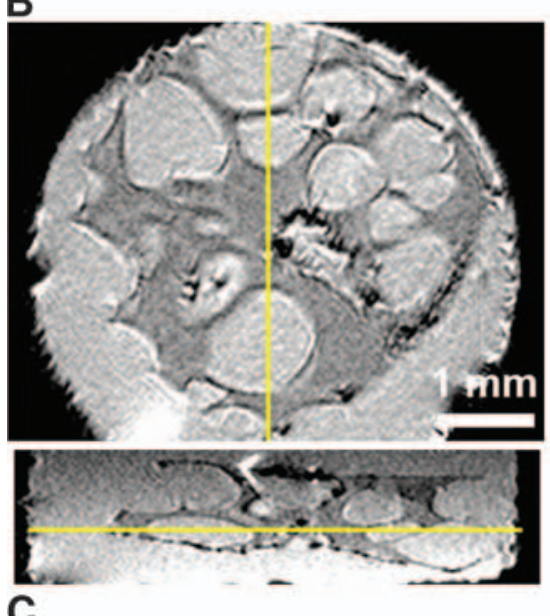

C
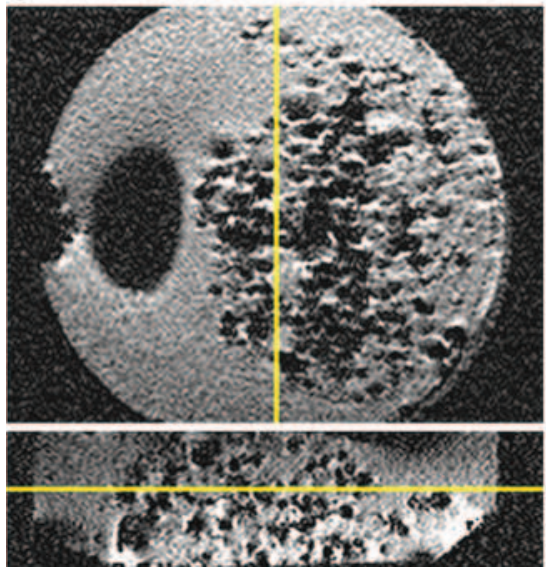

FIG. 8. MRI reveals cell distribution depending on scaffold architecture. (A) Microporous scaffold: Hyposignals are not evenly distributed throughout the gel. Cells are mainly located on the lower part and on the side of the gel, revealing poor integration of cells in the scaffold and sedimentation by side effects. Labeling condition $[\mathrm{Fe}]=2 \mathrm{mM}$; number of seeded cells: $20 \times 10^{3}$. (B) Macroporous scaffold: cells attached on the pore walls with heterogenous distribution. Labeling condition $[\mathrm{Fe}]=2 \mathrm{mM}$; number of seeded cells: $20 \times 10^{3}$. (C) Lamellar scaffold: Lamellar organization allows a homogeneous distribution of seeded cells within the gel. Labeling condition $[\mathrm{Fe}]=2 \mathrm{mM}$; number of seeded cells: $5 \times 10^{3}$.
Poorer resolution does not allow cells to be distinguished but may detect a global signal loss and a change in relaxation rates if cell density and iron load per cell are sufficient. ${ }^{9}$

In the present study, we found that low-resolution 1.5-T MRI, performed with a standard surface coil, allowed the contours of lamellar scaffolds to be depicted and a global change in relaxation rates $\mathrm{R} 2$ and $\mathrm{R} 2^{*}$ to be measured because of the presence of 5000 labeled cells. Change in scaffold relaxation rates could be correlated to the cell iron load and total iron concentration in the scaffold (Fig. 4), but scaffold structure and cell distribution could not be resolved.

By contrast, high-resolution MRI enabled the organization of cells within structured scaffolds serving as templates to be visualized. Spatial distribution of signal voids reflected the cell organization. The scaffold architecture could be seen together with labeled cell distribution for low cell density. Suitable parameters for accurate assessment of cell organization within the scaffold were identified as the highest spatial resolution (compatible with reasonable scan time), short echo time, and relatively low iron load per cell to produce small nonoverlapping signal voids.

Using the three different porous scaffolds, we could assess differences in cell-seeding efficiency and cell distribution 4 days after seeding. Microporous scaffolds did not allow homogeneous infiltration of cells seeded on the top of hydrated hydrogel; cells were mainly localized on the upper and side parts of the scaffold. By contrast, cells managed to penetrate macroporous scaffolds, which have much larger, partially interconnected pores. Cells were found on the wall of the pores, suggesting interactions with the polymer scaffold, blthough the density of cells retained on the scaffold was low. Cell seeding on lamellar porous scaffolds was made on lyophilized scaffold. The method of scaffold hydration using the cell suspension is favorable to cell penetration. Moreover, lamellar architecture was shown to enable homogeneous distribution of MSCs within the scaffold.

In addition to the qualitative observation of cell distribution, MRI may provide quantitative variables reflecting the number of cells in a scaffold or, alternatively, the cell iron load. Modifications in the signal histogram could be observed with only 1000 seeded cells with a 5-pg iron load. Averaged signal loss induced by seeded labeled cells was correlated with their iron load (Fig. 5) and cell density (Fig. 7) in the scaffold. Because signal heterogeneities caused by local field disturbances can be observed at high resolution, the standard deviation increased from $25 \%$ to $63 \%$ and from $25 \%$ to $46 \%$ of the mean SNR, correlated with iron load and cell density, respectively. The SD and more generally the whole histogram of signal were also representative of the labeling and density of cells within scaffolds.

The last goal of the work was to verify that high-resolution MRI allows accurate detection of scaffolds and cell seeding under in vivo condition. Lamellar scaffolds implanted subcutaneously in mice were successfully depicted using the HTS coil, with a resolution of $60 \times 60 \times 80 \mu^{3}$ for an acquisition time of $44 \mathrm{~min}$. Scaffolds containing nonlabeled cells show a signal comparable with that of muscle but were clearly distinguished from subcutaneous adipose tissue. Scaffolds containing labeled cells could be differentiated from control scaffolds by lower mean intensity and larger SD, reflecting the localized signal heterogeneities induced by the magnetic cells. We found a correlation between cell density and signal loss. Phase images 
FIG. 9. In vivo imaging of lamellar scaffolds implanted subcutaneously in mice. Two lamellar scaffolds (one with nonlabeled MSCs, the other with labeled MSCs) were implanted side by side subcutaneously in each mouse and imaged immediately after implantation using the hightemperature superconducting coil and a 3D gradient echo sequence $(\mathrm{TE}=13 \mathrm{~ms}$, field of view $=20 \times 20 \times 5 \mathrm{~mm}^{3}$, voxel size $=60 \times 60 \times 80 \mu^{3}$, $\left.\mathrm{t}_{\mathrm{acq}}=44 \mathrm{~min}\right)$. Sagittal slices are shown $(\mathrm{bar}=2 \mathrm{~mm})$. (a) Mouse 1: Number of seeded cells, $7.5 \times 10^{3}$; labeling conditions, $[\mathrm{Fe}]=0$ and $2 \mathrm{mM}$. (b) Mouse 2: Number of seeded cells, $37.5 \times 10^{3}$; labeling conditions, $[\mathrm{Fe}]=0$ and $2 \mathrm{mM}$. (c) Mouse 3: Number of seeded cells, $37.5 \times 10^{3}$; labeling conditions $[\mathrm{Fe}]=0$ and $0.2 \mathrm{mM}$.

AU10 The modulus signal (left column) and the phase image (right column) are displayed. Scaffolds can be clearly distinguished from the adipose tissue, which appears as hyposignal areas, and from skin and muscle structures. Scaffold with labeled cells is depicted by white arrows on the left of the field of view and scaffole with nonlabeled cells by yellow arrows on the right. The scaffolds with labeled cells show a moreheterogeneous and lower signal than the control scaffolds.
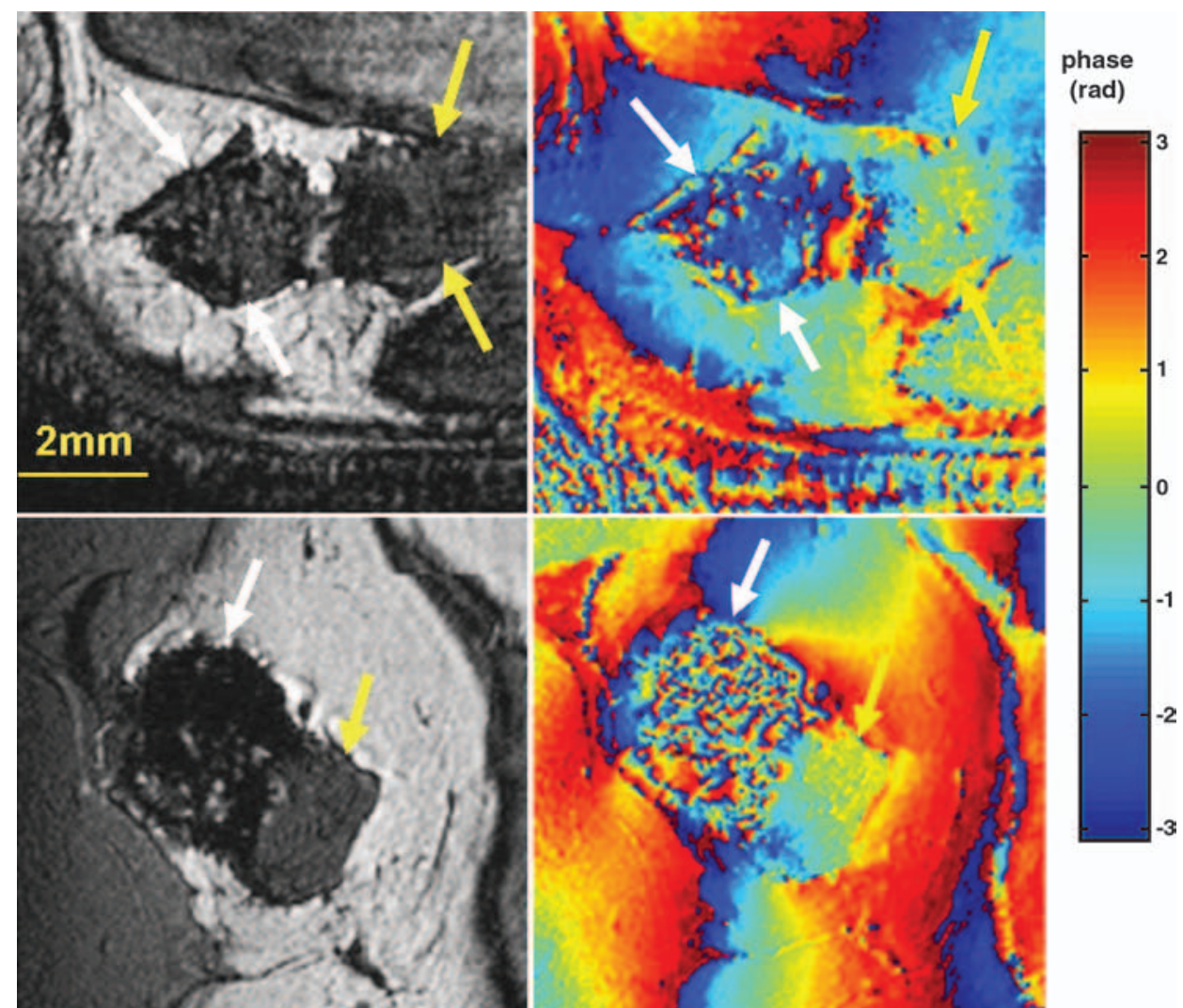
The signal decrease depends

on the number of seeded cells and on the labeling conditions (Table 2). The presence of labeled cells in the scaffold results in numerous, rapidly varying, phase shift (from $-\pi$ to $\pi$ ), whereas the scaffold with nonlabeled cells shows a smooth phase evolution due to the localization gradients. Color images available online at www.liebertonline.com/ten.

were also demonstrated to depict labeled cells in scaffolds by the presence of phase distortions. Further study may address the becoming of implanted scaffolds and cells with time.

In conclusion, we demonstrated the potentialities of highresolution MRI, performed on a clinical 1.5-T device, for 3D nondestructive imaging of tissue constructs before and after in vivo implantation. Three-dimensional scaffold architecture as well as the quality of cell delivery procedure have been characterized using this technique. Although cellular constructs were observed here at an early stage, the method could be applicable for longitudinal long-term follow-up of cell transplants using a polymer scaffold as a temporary template.
It has been shown recently that cells with low iron load of $0.2 \mathrm{pg}$ could be detected in vitro and in vivo using the present imaging method. ${ }^{15}$ Therefore, cells transferred in biomaterials could be detected after proliferation and subsequent dilution of iron load. The use of 1.5-T MRI and reasonable acquisition time make this approach feasible in clinical applications. Combining high resolution with clinical compatibility, MRI could be useful in distinguishing the biomaterials from surrounding tissue and to follow cell migration throughout the scaffold or outside the scaffold toward neighboring areas.

The main limitation is that the presently used HTS coil permits high-resolution imaging in a relatively small vol- 
ume, close to the surface of the coil $(<15 \mathrm{~mm})$. However, in the future, phased arrays of cryocooled HTS coils could be constructed to perform high-resolution images over larger regions of interest.

In its present form, HTS coils, associated with biocompatible magnetic labeling of cells, could be useful in monitoring cellular transplants designed for developing skin, cartilage, or adipose tissue, or for bone regeneration ${ }^{3}$ and complement established optical and micro-computed tomography methods.

\section{Acknowledgments}

The authors thank Françoise Norol (Pitié Salpétrière Hospital, Paris) for providing human MSCs; Christine Ménager (LI2C, CNRS UMR 7612, University Pierre et Marie Curie, Paris) for providing magnetic nanoparticles; RoseMarie Dubuisson, Emeline Boriasse, and the CIERM for assistance in MRI experiments. This work was supported by a grant from ANR PCV to the "3D MIGMAG" project.

\section{Disclosure Statement}

AU8 thors.

No competing financial interests exist for any of the au-

\section{References}

1. Simpson, D., Liu, H., Fan, T.H., Nerem, R., Dudley, S.C. Jr. A tissue engineering approach to progenitor cell delivery results in significant cell engraftment and improved myocardial remodeling. Stem Cells 25, 2350, 2007.

AU9 2. Mather, M.L., Morgan, S.P., White, L.J., et al. Image-based characterization of foamed polymeric tissue scaffolds. Biomed Mater 3, 15011, 2008.

3. Xu, H., Othman, S.F., Magin, R.L. Monitoring tissue engineering using magnetic resonance imaging. J Biosci Bioeng 106, 515, 2008.

4. Riviere, C., Boudghene, F.P., Gazeau, F., et al. Iron oxide nanoparticle-labeled rat smooth muscle cells: cardiac MR imaging for cell graft monitoring and quantitation. Radiology 235, 959, 2005.

5. Deux, J.F., Dai, J., Riviere, C., et al. Aortic aneurysms in a rat model: in vivo MR imaging of endovascular cell therapy. Radiology 246, 185, 2008.

6. Bulte, J.W., Douglas, T., Witwer, B., et al. Magnetodendrimers allow endosomal magnetic labeling and in vivo tracking of stem cells. Nat Biotechnol 19, 1141, 2001.

7. Arbab, A.S., Liu, W., Frank, J.A. Cellular magnetic resonance imaging: current status and future prospects. Expert Rev Med Devices 3, 427, 2006.

8. Arbab, A.S., Frank, J.A. Cellular MRI and its role in stem cell therapy. Regen Med 3, 199, 2008.

9. Kraitchman, D.L., Bulte, J.W. Imaging of stem cells using MRI. Basic Res Cardiol 103, 105, 2008.

10. Dodd, S.J., Williams, M., Suhan, J.P., Williams, D.S., Koretsky, A.P., Ho, C. Detection of single mammalian cells by high-resolution magnetic resonance imaging. Biophys J 76, 103, 1999.

11. Bulte, J.W., Kraitchman, D.L. Iron oxide MR contrast agents for molecular and cellular imaging. NMR Biomed 17, 484, 2004.

12. Josephson, L., Tung, C.H., Moore, A., Weissleder, R. Highefficiency intracellular magnetic labeling with novel super-
paramagnetic-Tat peptide conjugates. Bioconjug Chem 10, 186, 1999.

13. Hinds, K.A., Hill, J.M., Shapiro, E.M., et al. Highly efficient endosomal labeling of progenitor and stem cells with large magnetic particles allows magnetic resonance imaging of single cells. Blood 102, 867, 2003.

14. Shapiro, E.M., Sharer, K., Skrtic, S., Koretsky, A.P. In vivo detection of single cells by MRI. Magn Reson Med 55, 242, 2006.

15. Smirnov, P., Poirier-Quinot, M., Wilhelm, C., et al. In vivo single cell detection of tumor-infiltrating lymphocytes with a clinical 1.5 Tesla MRI system. Magn Reson Med 60, 1292, 2008.

16. Terrovitis, J.V., Bulte, J.W., Sarvananthan, S., et al. Magnetic resonance imaging of ferumoxide-labeled mesenchymal stem cells seeded on collagen scaffolds-relevance to tissue engineering. Tissue Eng 12, 2765, 2006.

17. Heymer, A., Haddad, D., Weber, M., et al. Iron oxide labelling of human mesenchymal stem cells in collagen hydrogels for articular cartilage repair. Biomaterials 29, 1473, 2008.

18. Perea, H., Aigner, J., Heverhagen, J.T., Hopfner, U., Wintermantel, E. Vascular tissue engineering with magnetic nanoparticles: seeing deeper. J Tissue Eng Regen Med 1, 318, 2007.

19. Poirier-Quinot, M., Ginefri, J.C., Girard, O., Robert, P., Darrasse, L. Performance of a miniature high-temperature superconducting (HTS) surface coil for in vivo microimaging of the mouse in a standard $1.5 \mathrm{~T}$ clinical whole-body scanner. Magn Reson Med 60, 917, 2008.

20. Autissier, A., Letourneur, D., Le Visage, C. Pullulan-based hydrogel for smooth muscle cell culture. J Biomed Mater Res A 82, 336, 2007.

21. Chaouat, M., Le Visage, C., Autissier, A., Chaubet, F., Letourneur, D. The evaluation of a small-diameter polysaccharidebased arterial graft in rats. Biomaterials 27, 5546, 2006.

22. Wilhelm, C., Gazeau, F. Universal cell labelling with anionic magnetic nanoparticles. Biomaterials 29, 3161, 2008.

23. Le Visage, C., Chaubet, F., Autissier, A., Letourneur, D. Method for preparing porous scaffold for tissue engineering. EP patent application 07301451.6-1219. 2008.

24. Le Visage, C., Letourneur, D. Method for preparing porous scaffold for tissue engineering, cell culture and cell delivery. EP patent application 07301452.4-1219. 2008.

25. Wilhelm, C., Gazeau, F., Bacri, J.C. Magnetophoresis and ferromagnetic resonance of magnetically labeled cells. Eur Biophys J 31, 118, 2002.

26. Smirnov, P., Gazeau, F., Beloeil, J.C., Doan, B.T., Wilhelm, C., Gillet, B. Single-cell detection by gradient echo 9.4 T MRI: a parametric study. Contrast Media Mol Imaging 1, 165, 2006.

27. Darrasse, L., Ginefri, J.C. Perspectives with cryogenic RF probes in biomedical MRI. Biochimie 85, 915, 2003.

28. Hoehn, M., Kustermann, E., Blunk, J., et al. Monitoring of implanted stem cell migration in vivo: A highly resolved in vivo magnetic resonance imaging investigation of experimental stroke in rat. Proc Natl Acad Sci U S A 99, 16267, 2002.

29. Burg, K.J., Delnomdedieu, M., Beiler, R.J., et al. Application of magnetic resonance microscopy to tissue engineering: a polylactide model. J Biomed Mater Res 61, 380, 2002.

30. Stroh, A., Faber, C., Neuberger, T., et al. In vivo detection limits of magnetically labeled embryonic stem cells in the rat brain using high-field (17.6 T) magnetic resonance imaging. Neuroimage 24, 635, 2005. 
31. Ko, I.K., Song, H.T., Cho, E.J., Lee, E.S., Huh, Y.M., Suh, J.S In vivo $\mathrm{MR}$ imaging of tissue-engineered human mesenchymal stem cells transplanted to mouse: a preliminary study. Ann Biomed Eng 35, 101, 2007.

32. Saldanha, K.J., Piper, S.L., Ainslie, K.M., Kim, H.T., Majumdar, S. Magnetic resonance imaging of iron oxide labelled stem cells: applications to tissue engineering based regeneration of the intervertebral disc. Eur Cell Mater 16, 17, 2008.

33. Metz, S., Bonaterra, G., Rudelius, M., Settles, M., Rummeny, E.J., Daldrup-Link, H.E. Capacity of human monocytes to phagocytose approved iron oxide MR contrast agents in vitro. Eur Radiol 14, 1851, 2004.

34. Wilhelm, C., Billotey, C., Roger, J., Pons, J.N., Bacri, J.C., Gazeau, F. Intracellular uptake of anionic superparamagnetic nanoparticles as a function of their surface coating. Biomaterials 24, 1001, 2003.

35. Arbab, A.S., Yocum, G.T., Rad, A.M., et al. Labeling of cells with ferumoxides-protamine sulfate complexes does not inhibit function or differentiation capacity of hematopoietic or mesenchymal stem cells. NMR Biomed 18, 553, 2005.

36. Henning, T.D., Wendland, M.F., Golovko, D., et al. Relaxation effects of ferucarbotran-labeled mesenchymal stem cells at $1.5 \mathrm{~T}$ and $3 \mathrm{~T}$ : Discrimination of viable from lysed cells. Magn Reson Med 2009.

37. Wilhelm, C., Gazeau, F., Roger, J., Pons, J.N., Bacri, J.C. Interaction of anionic superparamagnetic nanoparticles with cells: kinetic analyses of membrane adsorption and subsequent internalization. Langmuir 18, 8148, 2002.
38. Pittenger, M.F., Mackay, A.M., Beck, S.C., et al. Multilineage potential of adult human mesenchymal stem cells. Science 284, 143, 1999.

39. Kim, M.R., Jeon, E.S., Kim, Y.M., Lee, J.S., Kim, J.H. Thromboxane A2 induces differentiation of human mesenchymal stem cells to smooth muscle-like cells. Stem Cells 2008.

40. Kostura, L., Kraitchman, D.L., Mackay, A.M., Pittenger, M.F., Bulte, J.W. Feridex labeling of mesenchymal stem cells inhibits chondrogenesis but not adipogenesis or osteogenesis. NMR Biomed 17, 513, 2004.

41. Farrell, E., Wielopolski, P., Pavljasevic, P., et al. Effects of iron oxide incorporation for long term cell tracking on MSC differentiation in vitro and in vivo. Biochem Biophys Res Commun 369, 1076, 2008.

42. Heyn, C., Bowen, C.V., Rutt, B.K., Foster, P.J. Detection threshold of single SPIO-labeled cells with FIESTA. Magn Reson Med 53, 312, 2005.

Address correspondence to: Florence Gazeau
Laboratoire Matière et Systèmes Complexes UMR 7057 CNRS

Université Paris - Diderot 10 rue Alice Domon et Léonie Duquet 75205 Paris Cedex 13, France

E-mail: florence.gazeau@univ-paris-diderot.fr 


\section{AUTHOR QUERY FOR TEC-2009-0015-POIRIER_1P}

AU1: Please provide authors' degrees.

AU2: Is short title OK?

AU3: "building" was added here. Is that correct?

AU4: Please spell out CHR.

AU5: "as" or "on"?

AU6: Parentheses have been deleted here and elsewhere. OK?

AU7: Was close to what?

AU8: Is disclosure statement OK?

AU9: Please provide names for all authors in all references.

AU10: Part labels a,b,c are provided in Figure legend 9, but it is not cited in the text, please provide. 